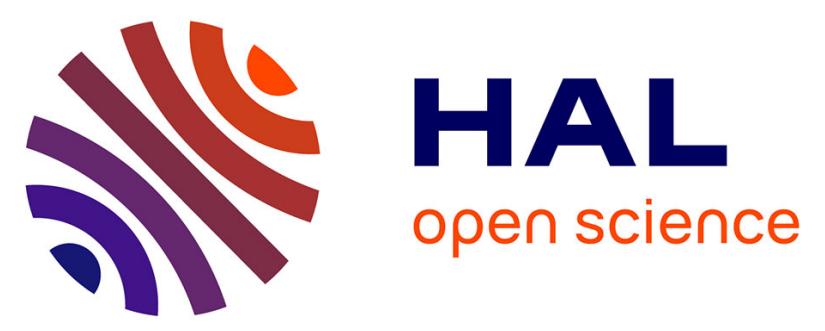

\title{
Modification of Bacterial Cellulose Membrane with 1,4bis(triethoxysilyl)benzene: a thorough physical-chemical characterization study
}

Andreia S Monteiro, Marcos de Oliveira, Silvia Santagneli, Carole Carcel, Torsten Gutmann, Gerd Buntkowsky, Michel Wong Chi Man, Hernane S Barud, Sidney Ribeiro

\section{To cite this version:}

Andreia S Monteiro, Marcos de Oliveira, Silvia Santagneli, Carole Carcel, Torsten Gutmann, et al.. Modification of Bacterial Cellulose Membrane with 1,4bis(triethoxysilyl)benzene: a thorough physical-chemical characterization study. Journal of Physical Chemistry C, 2021, 125 (8), pp.44984508. 10.1021/acs.jpcc.0c09837 . hal-03448061

\section{HAL Id: hal-03448061 \\ https://hal.science/hal-03448061}

Submitted on 25 Nov 2021

HAL is a multi-disciplinary open access archive for the deposit and dissemination of scientific research documents, whether they are published or not. The documents may come from teaching and research institutions in France or abroad, or from public or private research centers.
L'archive ouverte pluridisciplinaire HAL, est destinée au dépôt et à la diffusion de documents scientifiques de niveau recherche, publiés ou non, émanant des établissements d'enseignement et de recherche français ou étrangers, des laboratoires publics ou privés. 


\title{
Modification of Bacterial Cellulose Membrane with 1,4- bis(triethoxysilyl)benzene: a thorough physical-chemical characterization study
}

\author{
Andreia S. Monteiro, ${ }^{1}$ Marcos de Oliveira, Jr., ${ }^{2}$ Silvia Santagneli, ${ }^{1}$ Carole Carcel, ${ }^{3}$ Torsten Gutmann, ${ }^{4}$ \\ Gerd Buntkowsky, ${ }^{4}$ Michel Wong Chi Man, ${ }^{3}$ Hernane S. Barud, ${ }^{5}$ Sidney J. L. 5 Ribeiro ${ }^{1 *}$
}

1 Institute of Chemistry - São Paulo State University - UNESP, Araraquara, São Paulo 14800-060, Brazil

2 São Carlos Institute of Physics, University of São Paulo, PO Box 369, 13560-970, São Carlos, SP, Brazil

3 ICGM, Univ. Montpellier, CNRS, ENSCM, Montpellier, France

4 Institut für Physikalische Chemie, Technische Universität Darmstadt, 64287 Darmstadt, 12 Germany

5 University of Araraquara - UNIARA, Araraquara, São Paulo 14801-320, Brazil

\begin{abstract}
Bacterial cellulose $(\mathrm{BC})$ combined with organo-bridged porous silica nanoparticles offers potential opportunities to develop smart hybrid materials such as advanced drug delivery nanosystems. This work reports the preparation of Bacterial Cellulose Membrane (BCM) and their modification by in situ methodology with the organo-bridged precursor 1,4-bis(triethoxysilyl)benzene (BTEB). BTEB was successfully incorporated into the $B C M$, and spherical hybrid silica nanoparticles with heterogeneous particle size $(30-100 \mathrm{~nm})$ and probably porous structure, were formed and were characterized by Scanning Electron Microscopy (SEM), Transmission Electron Microscopy (TEM), Fourier Transform Infrared- Attenuated Total Reflectance (FTIR-ATR), Thermogravimetric analysis (TGA) and Solid State Nuclear Magnetic Resonance (NMR). We further combined solid-state NMR with Dynamic Nuclear Polarization (DNP) to achieve sensitivity enhancement and to selectively enhance the NMR signal of the hydrophobic BTEB moieties on the BCM surface. This allowed us to get more detailed structural information on the BTEB-BCM multicomponent material.
\end{abstract}

\section{INTRODUCTION}

The field of pharmaceutical technology is expanding rapidly because of the increasing number of drug delivery options. Successful drug delivery is influenced by multiple factors, one of which is the appropriate identification of materials for research and engineering of new drug delivery systems. Bacterial cellulose (BC) is one such biopolymer that fulfills the criteria for consideration as a drug delivery material. ${ }^{1,2}$ This biopolymer is a hydrogel formed of a threedimensional structure of fibrils with an exclusive combination of properties such as high surface area (high aspect ratio of fibers with diameter 20-100 nm), hydrophilic nature of BC (due to hydroxyl groups), resulting in high water-holding capacity (over 100 times of its own weight), better adherence, and increased moisture content, distinct physical and mechanical properties, including insolubility, biocompatibility, high crystallinity index $(84 \%-89 \%)$ and polymerization degree, high mechanical strength, with a tensile strength of $200-300 \mathrm{MPa}$, and a Young's modulus of up to $15 \mathrm{GPa}$ as well as high thermal stability (with a decomposition temperature ranging 
between 340 and $370{ }^{\circ} \mathrm{C}$ ). Due to its high purity (absence of lignin and hemicellulose), BC is considered as a non-cytotoxic, non-genotoxic, non-allergenic and highly biocompatible material.1${ }^{6}$ These excellent and unique properties of $\mathrm{BC}$, show a high potential as material in a wide range of high-tech domains including biomedical applications, and most notably in controlled drug-delivery systems. ${ }^{2,3,6} \mathrm{BC}$ has been used in several systems for drug delivery (see refs. ${ }^{2,3,6-9}$ ) or after some sort of physical or chemical modification in the form of nanocomposite materials with diverse polymeric matrices. ${ }^{10-12}$ Several BC products for drug delivery systems have been developed and marketed. ${ }^{13-17}$ These systems have been mainly tested in vitro in transdermal drug delivery, used as a temporary skin substitute and wound dressing in treatment of burns and chronic wounds, oral drug delivery and tissue engineering/regeneration. The BC can be modified with different nanomaterials opening new perspectives for the design of tailored drug-delivery systems based on this natural biopolymer.

Mesoporous silica nanoparticles (MSNs) have been applied as carriers of active drugs to develop drug delivery systems. ${ }^{18-24}$ Their outstanding structural and physicochemical properties, such as small particle size, high specific surface area and chemical and physical stabilities, ordered structure, tunable pore size, high chemical and physical stabilities, and hydroxyl groups available on their surface (exterior and interior of the pores), are amazing and can be tuned making them emerging nanocarriers for specific and controlled drug release, with low toxicity and biological behavior. The pores structure can promote drugs confinement, controlled loading and release processes avoiding drug degradation or premature release before achieving their target. In addition, the hydroxyl groups available in MSNs can be easily functionalize by functional groups favored by drug molecules in order to further enhance drug loading and releasing ability. ${ }^{18,23,25}$ In view of the potential of these two materials, the combination of $B C$ with MSNs for the design of drug-delivery systems, was the motivation for the development of this work.

The incorporation of suitable bridged organic groups endows the formed organo bridged MSNs properties such as improved hydrothermal and hydrolytic stability, adjustable biodegradability, high loading capacity towards specific drugs owing to high affinity, framework-induced stimuli-responsive release behavior and higher biocompatibility. Organo-bridged MSNs have recently been synthesized by hydrolysis and condensation reactions of $100 \%$ bridged organosilica precursors, without using any classical silica source such as tetraethoxysilane (TEOS). ${ }^{25-29} 1,4$-bis(triethoxysilyl)benzene (BTEB) is extensively used as bridged precursor to form benzene-bridged mesoporous silica nanoparticles with a variety of morphological and textural properties. ${ }^{28-34}$ The incorporation of organosilicates on the Bacterial Cellulose Membrane ( $\mathrm{BCM}$ ) with the formation of the silica nanoparticles on the fibers of the $\mathrm{BC}$, has been reported by some works. ${ }^{4,35-37}$ To the best of our knowledge, no report on the incorporation of organo-bridged precursor in the $\mathrm{BC}$ has been published so far, as well as the preparation of porous organo-silica nanoparticles on BC.

In this context, this work reports the preparation of $\mathrm{BCM}$ and their modification by in-situ methodology with the organo-bridged precursor BTEB. The modification of BCM with BTEB emerged as a promising strategy to the design of high-performance $B C$ as a potential strategy for drug-delivery systems. The BCM-BTEB was studied by several characterization techniques, namely, Scanning electron microscopy (SEM), Transmission electron microscopy (TEM), Fourier transform infrared- attenuated total reflectance (FTIR-ATR), Solid state nuclear magnetic resonance (RMN) and Thermogravimetric analysis (TGA) to obtain information on morphological, structural and chemical composition.

Solid state nuclear magnetic resonance is a powerful characterization tool for amorphous compounds. However, this technique suffers from low sensitivity, especially in the case of low 
abundant nuclei, such as ${ }^{29} \mathrm{Si}$ and ${ }^{13} \mathrm{C}$ or species with very low concentration, as is the case for functional species in cellulose surfaces. To overcome this issue, we combined solid-state NMR with Dynamic Nuclear Polarization (DNP) to achieve sensitivity enhancement. ${ }^{38-43}$ In the DNP technique, typically paramagnetic radicals are introduced within the sample using post-synthesis impregnation with a glass forming solution (DNP matrix) ${ }^{44-47}$ The sample is then pumped with microwave ( $\mathrm{mw}$ ) radiation, saturating electron paramagnetic resonance transitions while the NMR experiment is performed and a part of the strong polarization of electronic spins (about 660 times greater than the polarization of ${ }^{1} \mathrm{H}$ nuclear spins) is transferred to the NMR-active nuclei (details can be found in several recent reviews). ${ }^{48,49}$ This combination of high resolution high field NMR techniques with the increase in sensitivity provided by the DNP technique is an essential tool for the characterization of species on the surface of nanostructured materials, ${ }^{50-52}$ including cellulose based materials.53-56 In a very recent work, Gutmann et al. have demonstrated that DNP can be used to selectively enhance those groups on the surface of cellulose fibers by an appropriate choice of the DNP-matrix. ${ }^{57}$ They have shown that compatibility between the solvation properties of both DNP-matrix and target molecule is determinant for the DNP efficiency. Following their conclusions, we have selected organic solvents for our DNPmatrix in order to selectively enhance the NMR signal of the hydrophobic BTEB moieties on BCM surface.

The BTEB-based nanoparticles incorporated in BCM are obtained from an in situ methodology, which may lead to a final structure for the nanoparticles which differs from the structure reported in the literature for BTEB-based nanoparticles alone. For this reason, we report here not only the successful incorporation of organosilane nanoparticles on cellulose, but also a detailed structural characterization of the surface species by techniques sensitive to the local-range order, such as DNPNMR. As explained above, due to the sensitivity enhancement, the DNP technique provides extremely valuable information about species on BCM surface, which could not be obtained by other techniques.

\section{EXPERIMENTAL}

2.1. Material and Reagents.

Tetraethylorthosilicate, TEOS ( $\geq 99 \%)$, 1,2-dibromoethane (99\%), 1,4-dibromobenzene (98\%), tetrahydrofuran, THF ( $\geq 99 \%$, analytical grade), hexane ( $\geq 99 \%$, analytical grade), sodium hydroxide (analytical grade), and Agar were supplied from Sigma-Aldrich. Yeast extract was from Kasvi, peptone $G$ was from Acumedia and d-glucose anhydrous (analytical grade), disodium hydrogen phosphate (analytical grade), citric acid (analytical grade), magnesium sulphate heptahydrate (analytical grade), and monopotassium phosphate (analytical grade) were purchased from Synth. Ethanol (99,8\%, analytical grade) was purchased from Lac. Ultrapure water (Millipore, specific resistivity: $18 \mathrm{M} \Omega \mathrm{cm}$ ) was used throughout the experiments. The strain Komagataeibacter Xylinus (ATCC53524) was supplied by André Tobello Foundation, Campinas-SP, Brazil.

2.2. Preparation of Organosilica precursor 1,4-bis(triethoxysilyl)benzene.

Organosilica source, 1,4-bis(triethoxysilyl)benzene (BTEB), was prepared by the method reported in the literature. ${ }^{58}$ The reaction (Scheme 1 ) was carried out under nitrogen by use of a vacuum line and dried solvents. To a mixture of magnesium turnings $(15.0 \mathrm{~g})$ in $50.0 \mathrm{~mL}$ of THF ( $0.62 \mathrm{~mol}$ ) under nitrogen 20 drops of 1,2-dibromoethane were added, under vigorous stirring during $5 \mathrm{~min}$. To this solution, $450 \mathrm{~mL}$ of TEOS ( $2.02 \mathrm{~mol})$ in $250 \mathrm{~mL}$ of THF ( $3.09 \mathrm{~mol}$ ) were added and the mixture was brought to reflux to activate the magnesium turnings. This can be evidenced by ethylene gas evolving (formed from the reaction of 1,2-dibromoethane with metallic magnesium. When no more gas bubbles are formed, the solution was cooled to $20^{\circ} \mathrm{C}$. Afterward, a solution of $26.1 \mathrm{~mL}$ of 1,4 -dibromobenzene $(20.4 \mathrm{mmol})$ in $1100.0 \mathrm{~mL}$ of THF $(1.23 \mathrm{~mol})$ was 
added dropwise for $2 \mathrm{~h}$. Within $30 \mathrm{~min}$ of initiating the addition, the reaction became mildly exothermic. Care should be taken so that the temperature of the reacting mixture never exceed $40^{\circ} \mathrm{C}$ After the completion of the BTEB addition, the grey-green mixture was refluxed for $2 \mathrm{~h}$ at 60 ${ }^{\circ} \mathrm{C}$ and then left at room temperature for $12 \mathrm{~h}$. $200.0 \mathrm{~mL}$ of hexane was added to precipitate any remaining magnesium salts in solution, and the mixture was quickly filtered under nitrogen to yield a clear, light brown solution. Hexane and THF were removed in vacuum, and the remaining TEOS was distilled off under vacuum leaving a brown oil. The oil was distilled $\left(135^{\circ} \mathrm{C} / 0.05 \mathrm{mmHg}\right)$ to give a clear colorless oil $(1.72 \mathrm{~g}, 67 \%$ yield). $1 \mathrm{H} \mathrm{NMR} \mathrm{(CDCl3)} \mathrm{?} 7.67$ (s, $4 \mathrm{H}, \mathrm{ArH}), 3.84$ (q, $12 \mathrm{H}$, $\left.\mathrm{OCH}_{2} \mathrm{CH}_{3}\right), 1.22\left(\mathrm{t}, 18 \mathrm{H}, \mathrm{OCH}_{2} \mathrm{CH}_{3}\right)$.

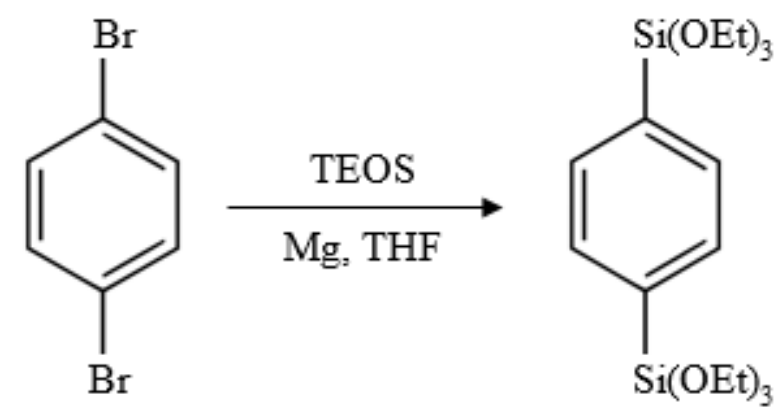

Scheme 1. Synthesis of 1,4-bis(triethoxysilyl)benzene (BTEB)

2.3. Preparation of Bacterial Cellulose Organic-Inorganic Hybrid Membrane.

a. Preparation of Bacterial Cellulose Membrane.

The strain used was Komagataeibacter Xylinus (ATCC53524). BCM were prepared following the procedures adapted from literature. ${ }^{59}$ An aliquot of the bacterium Komagataeibacter Xylinus (ATCC53524) was replicated to a sterile solid medium plate HS (Hestrim-Schramm) containing 12 $\mathrm{g}$ of glucose $(0.067 \mathrm{~mol}), 3 \mathrm{~g}$ of yeast extract, $3 \mathrm{~g}$ of peptone $\mathrm{G}, 1.62 \mathrm{~g}$ of disodium hydrogen phosphate ( $0.011 \mathrm{~mol}), 0.69 \mathrm{~g}$ of citric acid $(3.59 \mathrm{mmol}), 15 \mathrm{~g}$ of agar and $585 \mathrm{~mL}$ of milipore water $(32.5 \mathrm{~mol})$. After growth time, the microorganism was inoculated into sterile liquid culture medium consisting of $50 \mathrm{~g}$ of glucose $(0.277 \mathrm{~mol}), 4 \mathrm{~g}$ of yeast extract, $0.73 \mathrm{~g}$ of magnesium sulphate heptahydrate $(2.96 \mathrm{mmol}), 2 \mathrm{~g}$ of monopotassium phosphate $(0.015 \mathrm{~mol}), 20 \mathrm{~mL}$ of ethanol ( $0.342 \mathrm{~mol}$ ) and $980 \mathrm{~mL}$ of millipore water $(54.4 \mathrm{~mol})$ and maintained for $72 \mathrm{~h}$ in an oven with air circulation and with constant temperature at $28^{\circ} \mathrm{C}$. Subsequently, the BCM produced were purified following the subsequent procedure: washing the BCM with water 5 times per day during 3 days; washing the $\mathrm{BCM}$ with water at $80^{\circ} \mathrm{C}$ during $50 \mathrm{~min}$; immersion of the $\mathrm{BCM}$ in 100 $\mathrm{mL}$ of an ethanolic solution of sodium hydroxide $(0.1 \mathrm{M})$ at $80^{\circ} \mathrm{C}$ during $50 \mathrm{~min}$; and washing again with millipore water until $\mathrm{pH} 7.0$. Finally the $\mathrm{BCM}$ was dried at $80^{\circ} \mathrm{C}$ for $24 \mathrm{~h}$. The resulting sample will be called in the following $194 \mathrm{BCM}$.

b. Preparation of Bacterial Cellulose Membrane functionalized with BTEB.

The organosilane BTEB were incorporated into BCM by in situ methodology, following similar procedure for the preparation of the $B C M$, with the exception the addition of $1 \%(w / w)$ of organosilane BTEB (with respect to the amount of glucose of the liquid culture medium), in the liquid culture medium, at the same time as the microorganism (Scheme 2). The resulting sample will be called in the following BCM-BTEB. 


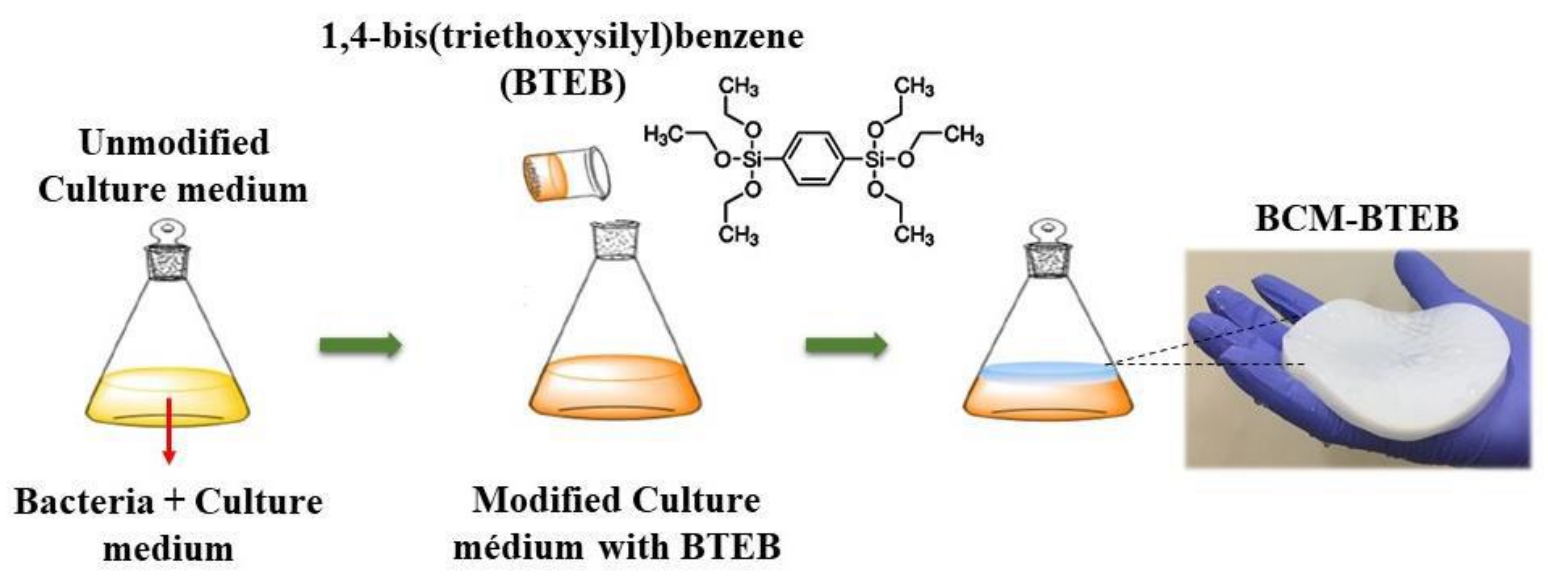

Scheme 2. Schematic Representation of the Preparation of Bacterial Cellulose Membrane 205 modified with BTEB.

\subsection{Physicochemical Characterization.}

Scanning electron microscopy (SEM) and energy-dispersive X-ray spectroscopy (EDS) were performed at the European Membrane Institute (EMI), Montpellier, France, using a high-resolution environmental scanning electron microscope (Hitachi S4800 model) and an energy-dispersive X-ray spectrometer (Oxford Instruments X-Max N SDD), respectively. The samples were analyzed with coating of $1 \mathrm{~nm}$ thick carbon layer.

Transmission electron microscopy (TEM) images were performed at the Ecole Nationale Supérieure de Chimie de Montpellier (ENSCM), France, using a Philips CM30T electron microscope with a LaB6 filament as the source of electrons, operated at $80 \mathrm{kV}$ to minimize beam damage. The BCM-BTEB sample was dispersed in high purity ethanol under sonication and a drop of the colloidal suspension was placed on a holey carbon TEM grid and left to dry at ambient conditions. The average particle size and standard deviations of nanomaterials incorporated into the BCM were calculated from the diameters of 50 particles randomly selected from SEM micrographs, and using the ImageJ software.

The Fourier transform infrared (FTIR) spectra were collected with a Bruker Vertex 70 spectrophotometer equipped with an attenuated total reflectance (ATR) accessory in the range of 650$4000 \mathrm{~cm}^{-1}$, with $4 \mathrm{~cm}^{-1}$ resolution and 16 scans at the Institut Charles Gerhardt 224 Montpellier (ICGM) at the ENSCM, Montpellier, France.

Thermogravimetric analysis (TGA) were carried out on a Q50 V6.7 Build 203 from TA-Instruments at the ENSCM. The experiments were performed in the temperature range of 50 to $900^{\circ} \mathrm{C}$ at a heating rate of $10^{\circ} \mathrm{C} \mathrm{min}^{-1}$ under an oxygen atmosphere, $60 \mathrm{~mL} \mathrm{~min}^{-1}$.

Standard ${ }^{29} \mathrm{Si}$ and ${ }^{13} \mathrm{C}$ solid state NMR experiments were collected on a Bruker Avance III HD 400WB spectrometer $(9.4 \mathrm{~T})$, using a $4 \mathrm{~mm}$ double resonance probe. The spectra were acquired with a MAS frequency of $10 \mathrm{kHz} .{ }^{29} \mathrm{Si}\left\{{ }^{1} \mathrm{H}\right\}$ and ${ }^{13} \mathrm{C}\left\{{ }^{1} \mathrm{H}\right\}$ cross polarization magic angle spinning (CPMAS) spectra were recorded using a contact time of 4.5 and $2.0 \mathrm{~ms}$, and a typical repetition delay of 4 and $3 \mathrm{~s}$, respectively. All spectra were acquired with TPPM ${ }^{60}$ proton decoupling during the data acquisition. Chemical shifts are reported relative to tetramethylsilane (TMS).

All solid-state DNP experiments were carried out on a Bruker Avance III $400 \mathrm{MHz}$ NMR spectrometer equipped with an Ascend 400 DNP magnet and a $3.2 \mathrm{~mm}$ triple resonance $1 \mathrm{H} / \mathrm{X} / \mathrm{Y}$ low-temperature MAS probe. The microwave $(\mathrm{mw})$ irradiation was provided by a $9.7 \mathrm{~T}$ Bruker gyrotron system operating 
at $263 \mathrm{GHz}$. The samples were ground in a ball mill apparatus (400 rpm during $2 \mathrm{~min}$ ). The powdered samples were prepared before measurements by mixing ca.

$10 \mathrm{mg}$ of the sample with ca. $20 \mu \mathrm{L}$ of the polarizing solution, which consisted of a hydrophobic 15 $\mathrm{mM}$ solution of TEKPol radical in 1,1,2,2-Tetrachloroethane (TCE) ${ }^{61}$ Also, samples prepared with a second polarizing solution, consisting of $15 \mathrm{mM}$ solution of bis-TEMPO-bis-ketal (bTbk) ${ }^{62}$ in Dimethyl sulfoxide (DMSO), were measured to confirm or exclude the 244 presence of ${ }^{13} \mathrm{C}$ lines overlapping with the TCE signal. The ${ }^{13} \mathrm{C}\left\{{ }^{1} \mathrm{H}\right\}$ and ${ }^{29} \mathrm{Si}\left\{{ }^{1} \mathrm{H}\right\}$ CPMAS 245 spectra with and without mw irradiation were acquired with a MAS frequency of 8-10 kHz. 246 The sample temperature was nominally $117 \mathrm{~K}$ (without $\mathrm{mw}$ ) and $128 \mathrm{~K}$ (with $\mathrm{mw}$ ), and was 247 stabilized by a Bruker BioSpin low temperature MAS cooling system. ${ }^{13} \mathrm{C}\left\{{ }^{1} \mathrm{H}\right\}$ and ${ }^{29} \mathrm{Si}\left\{{ }^{1} \mathrm{H}\right\} 248 \mathrm{CPMAS}$ NMR spectra were recorded with ${ }^{1} \mathrm{H}$ excitation pulses of $2.5 \mu \mathrm{s}$, a contact time of $2249 \mathrm{~ms}$, a typical repetition delay of $3.6 \mathrm{~s}$. Dipolar interactions with protons were decoupled 250 employing SPINAL-64. ${ }^{63}$ DNP enhanced ${ }^{13} \mathrm{C}\left\{{ }^{1} \mathrm{H}\right\}$ and ${ }^{29} \mathrm{Si}\left\{{ }^{1} \mathrm{H}\right\}$ heteronuclear correlation 251 (HETCOR) experiments were performed using the pulse sequence proposed by van Rossum et 252 al., ${ }^{64}$ which employs FSLG (frequency-switched Lee-Goldburg) homonuclear decoupling 253 during ${ }^{1} \mathrm{H}$ evolution. A decoupling field of $90 \mathrm{kHz}$ was used. Short contact times of $200 \mu$ s and $254500 \mu$ s were chosen respectively for ${ }^{13} \mathrm{C}\left\{{ }^{1} \mathrm{H}\right\}$ and ${ }^{29} \mathrm{Si}\left\{{ }^{1} \mathrm{H}\right\}$ $\mathrm{CP}$ transfer, in order to select the 255 correlations between nearest ${ }^{13} \mathrm{C} /{ }^{29} \mathrm{Si}$ and ${ }^{1 \mathrm{H}}$ neighbors.

\section{RESULTS AND DISCUSSION}

The purification of the BCM-BTEB after their preparation includes several washings, namely with water, hot water and ethanolic solution of sodium hydroxide $(0.1 \mathrm{M})$. As such, this procedure can be considered in order to evaluate the stability of the BTEB on the BCM. This assessment is an important criterion for the validation of the obtained product.

The SEM images of pristine BCM show smooth longitudinal fiber-like structures. After the incorporation of the organosilane BTEB, the micrographs reveal the formation of spherical organosilica nanoparticles with heterogeneous particle size (30-100 nm), imparting nanoscale surface roughness (Figure 1). In the SEM images of each sample is identified (red square) where the X-ray elemental mappings (Figure 3) were performed. The TEM micrographs of the BCM-BTEB, Figure 2, indicate that these nanoparticles might probably present porous structure. The $X$-ray elemental mappings (Figure 3), obtained during SEM experiment, evidence the successful incorporation of the BTEB on the $\mathrm{BCM}$ through the identification of element $\mathrm{Si}$. Indeed, the $\mathrm{C}$ and $\mathrm{O}$ elements are homogeneously distributed throughout the BCM surface as expected for both samples. However while BCM (Figure 3A) does not present any Si element, BCM-BTEB sample demonstrates that $\mathrm{Si}$ containing nanoparticles are homogeneously distributed on the $B C M$ surface on a microscopic scale (Figure $3 \mathrm{~B}$ ). The presence of element $C$ in the samples in part, are due to the carbon characteristic of cellulose and organosilane BTEB and also of the carbon layer deposited on the samples which was used to increase conductivity during the SEM analysis. 

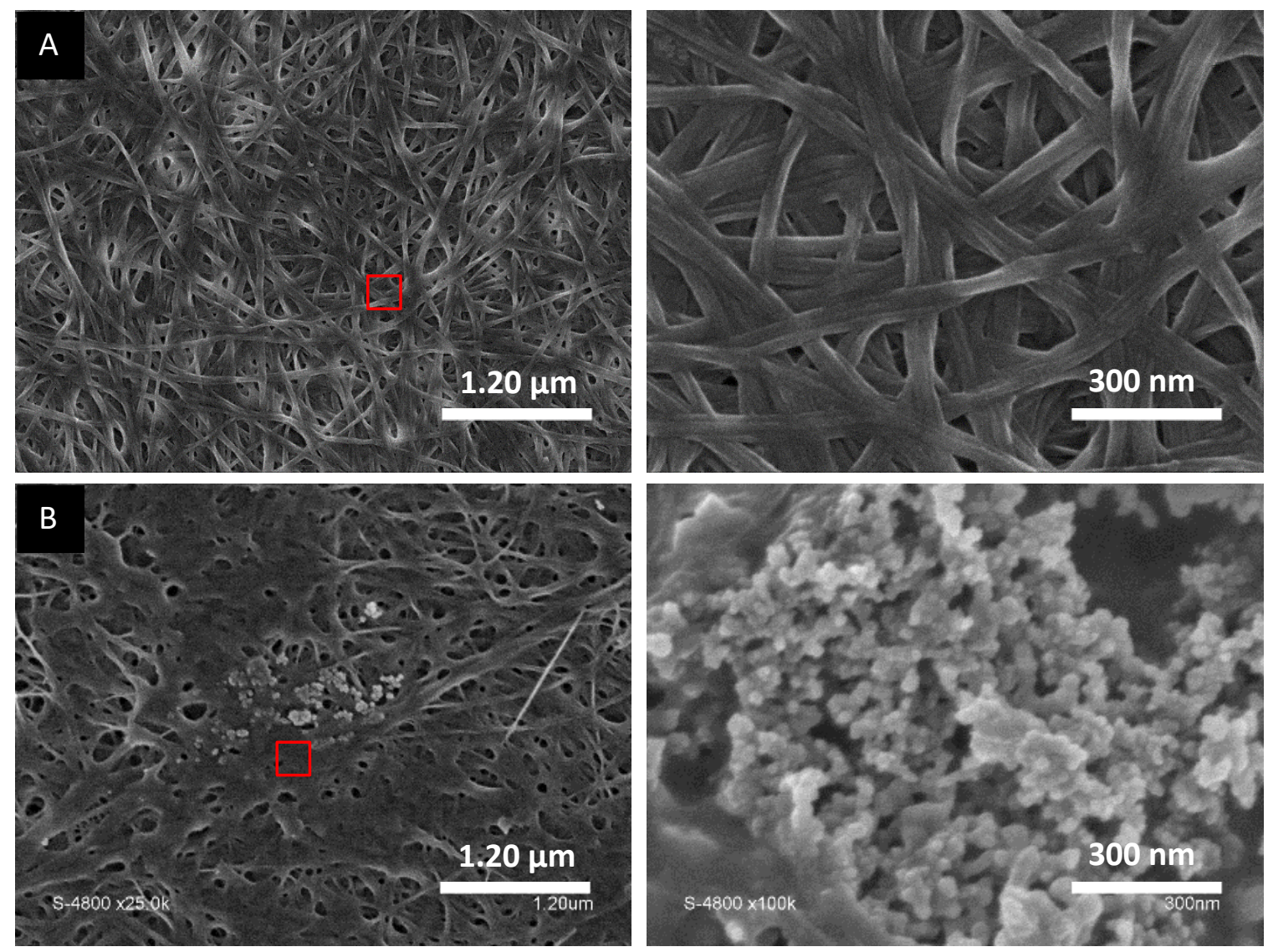

Figure 1. SEM micrographs with different magnifications of (A) BCM and (B) BCM-BTEB samples. The red square is the region where the $X$-ray elemental mappings was performed.
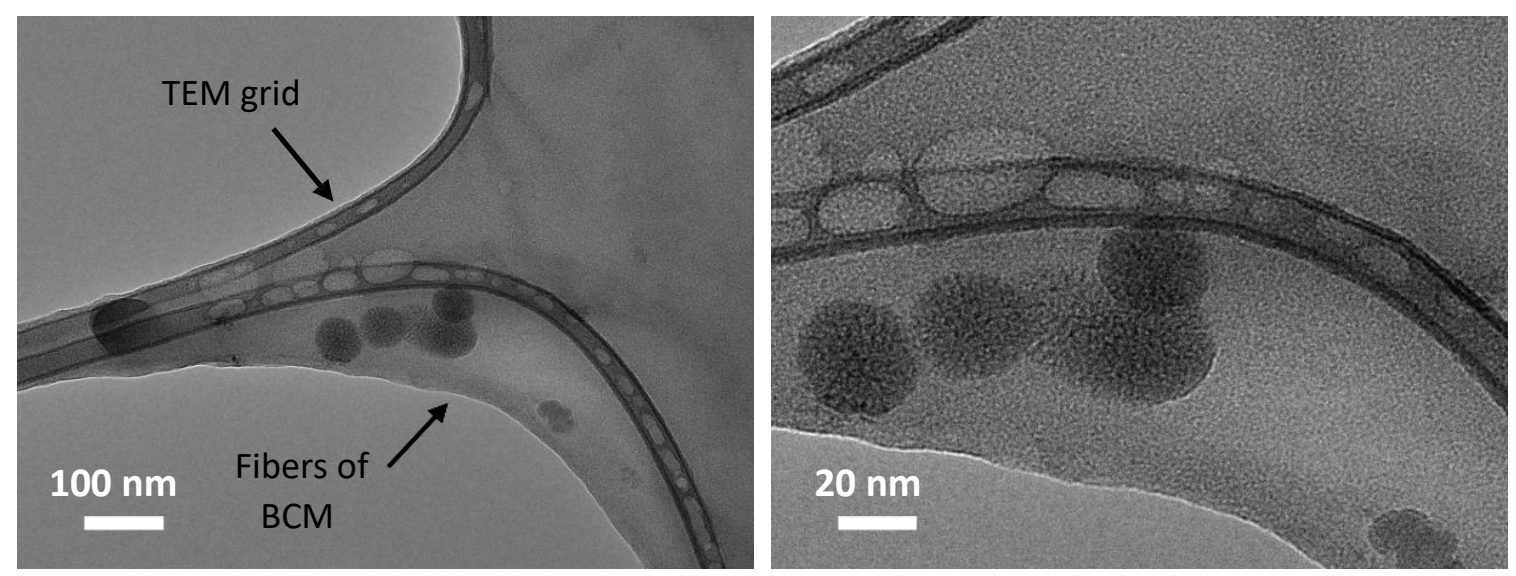

Figure 2. TEM micrographs with different magnifications of BCM-BTEB sample. 


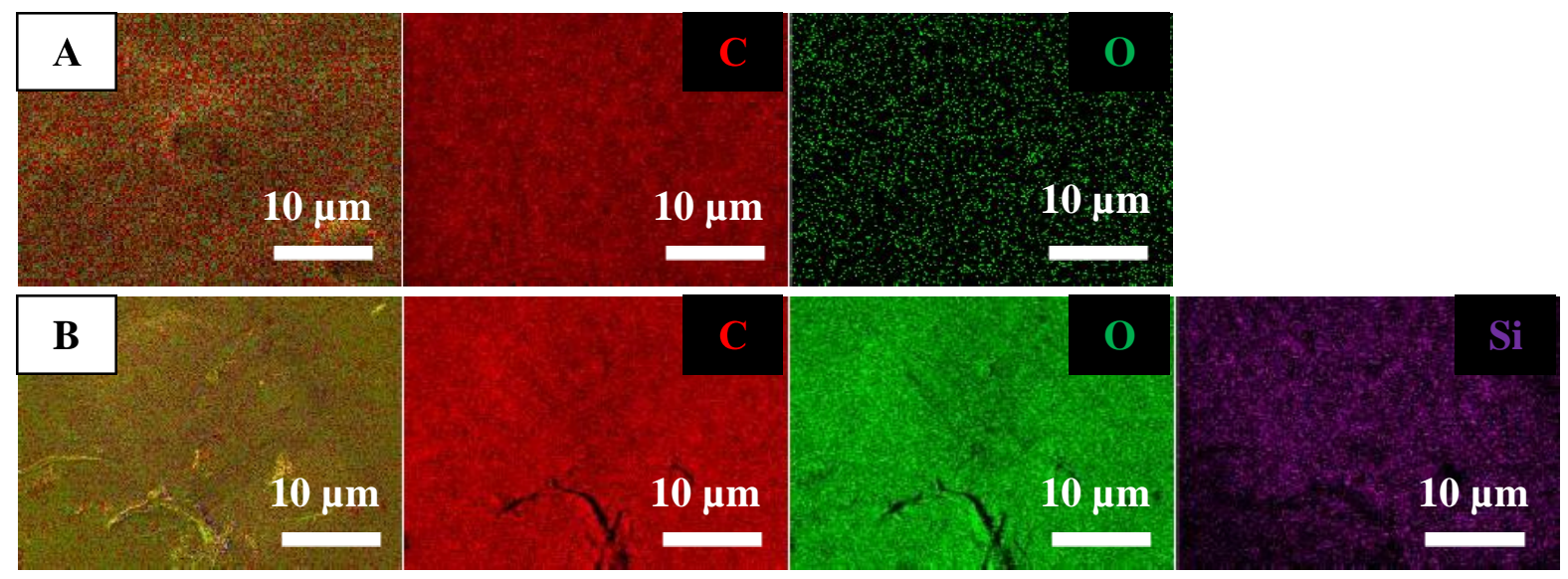

Figure 3. Low-magnification SEM image of (A) BCM and (B) BCM-BTEB sample, and corresponding $\mathrm{X}$-ray elemental mappings.

The FTIR-ATR spectrum of pristine BCM (Figure 4b) displays the characteristic bands of cellulose: stretching (3500-3300 $\left.\mathrm{cm}^{-1}\right)$ and symmetric bending $\left(1645 \mathrm{~cm}^{-1}\right)$ vibrations of $\mathrm{H}$-bonded hydroxyl groups and adsorbed water, respectively; $\mathrm{CH}$ and $\mathrm{CH}_{2}\left(\mathrm{CHOH} ; \mathrm{CH}_{2} \mathrm{OH}\right.$ ) stretching (3000$\left.2870 \mathrm{~cm}^{-1}\right)$; $\mathrm{C}-\mathrm{OH}$ and $\mathrm{CH}$ bending (1430-1330 $\left.\mathrm{cm}^{-1}\right)$; C-O (-C-O-H) stretching (1200-1000 $\left.\mathrm{cm}^{-1}\right)$; C$\mathrm{O}(\mathrm{C}-\mathrm{O}-\mathrm{C})$ stretching $\left(1150-1000 \mathrm{~cm}^{-1}\right) ; \mathrm{CH}_{2}$ asymmetric bending in plane $\left(900-700 \mathrm{~cm}^{-1}\right)$ and $\mathrm{OH}$ bending out of the plane $\left(700-650 \mathrm{~cm}^{-1}\right)$ vibrations..$^{59,65} \mathrm{In}$ the spectrum of the BCM-BTEB (Figure $4 a)$, additional vibrational bands are detected, when compared with $B C M$, that are assigned to the incorporated organo-bridged silica sources BTEB (red squares): $\mathrm{C}-\mathrm{H}$ symmetric stretching of $-\mathrm{CH}_{3}$ $\left(2974 \mathrm{~cm}^{-1}\right), \mathrm{C}-\mathrm{H}$ antisymmetric stretching of $-\mathrm{CH}_{2}\left(2932 \mathrm{~cm}^{-1}\right), \mathrm{C}=\mathrm{C}$ stretching and $\mathrm{C}-\mathrm{H}$ deformation in plane of Si-Phenyl $\left(1481 \mathrm{~cm}^{-1}\right), \mathrm{C}=\mathrm{C}$ stretching and $\mathrm{C}-\mathrm{H}$ deformation in plane 2 stretching SiPhenyl of Si-Phenyl $\left(1481 \mathrm{~cm}^{-1}\right), \mathrm{C}-\mathrm{H}$ symmetric deformation of $-\mathrm{CH}_{2}\left(1390 \mathrm{~cm}^{-1}\right)$, antisymmetric stretching of Si-O-Si $\left(1145 \mathrm{~cm}^{-1}\right)$, in-plane stretching Si-O of $\equiv \mathrm{Si}-\mathrm{O}\left(958\right.$ and $\left.811 \mathrm{~cm}^{-1}\right)$ and C-H outof-plane ring deformation of Si-Phenyl $\left(702 \mathrm{~cm}^{-1}\right)$ vibrations. ${ }^{65-68}$

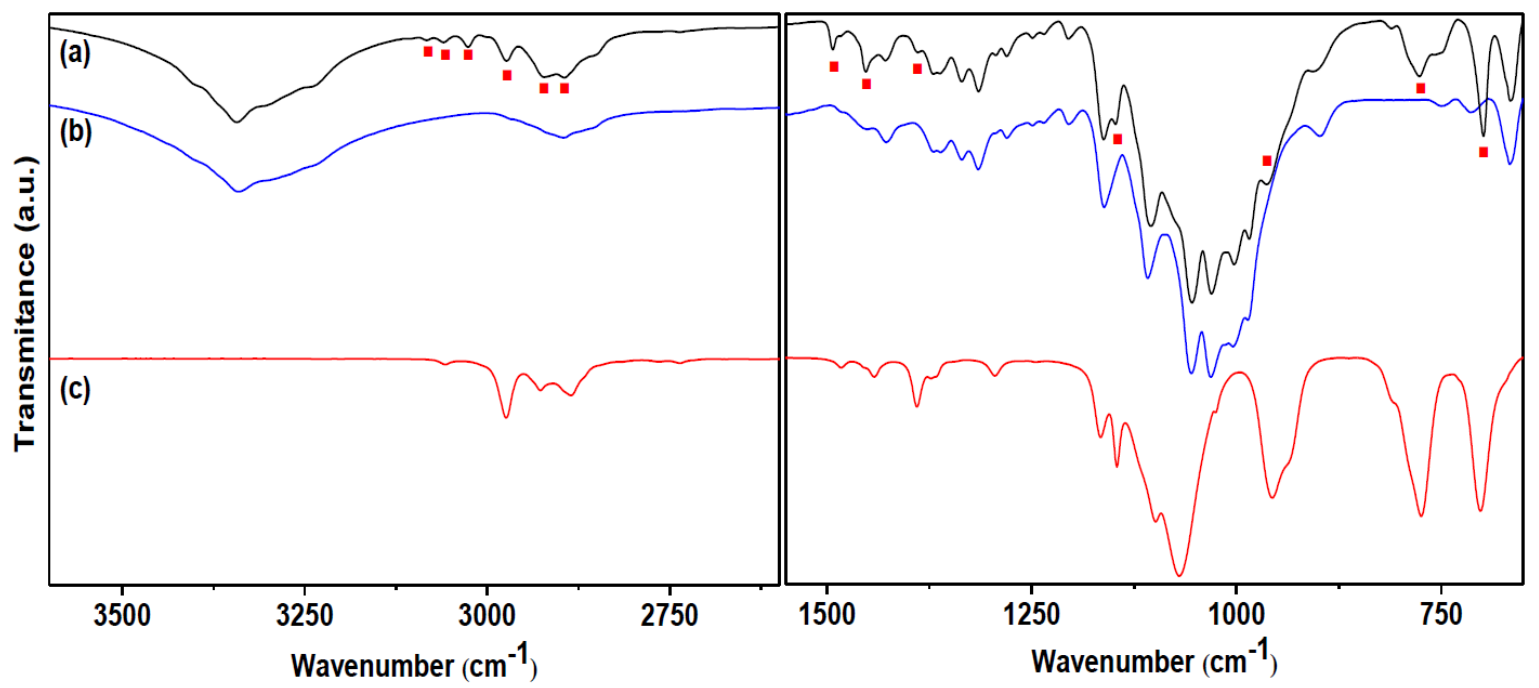

Figure 4. FTIR-ATR spectra of (a) BCM-BTEB, (b) BCM and (c) BTEB in the $3600-2600 \mathrm{~cm}^{-1}$ (left) and $1550-650 \mathrm{~cm}^{-1}$ (right) range. The red squares highlight the characteristic peaks of BTEB. 
The ${ }^{29} \mathrm{Si}\left\{{ }^{1} \mathrm{H}\right\} \mathrm{CP}$ MAS NMR spectra of BCM-BTEB (Figure 5), present peaks at $-59,-70$ and $78 \mathrm{ppm}$, which are respectively associated to $\mathrm{T}^{1}\left[\mathrm{CSi}(\mathrm{OR})_{2}(\mathrm{OSi})\right], \mathrm{T}^{2}\left[\mathrm{CSi}(\mathrm{OR})(\mathrm{OSi})_{2}\right]$ and $\mathrm{T}^{3}\left[\mathrm{CSi}(\mathrm{OSi})_{3}\right]$ silicon environments, corresponding to the condensation rate of organosilane BTEB through 1, 2 and 3 Si-O-Si linkages, ${ }^{69}$ indicating the incorporation of BTEB in the BCM successfully. The successful incorporation of BTEB in the material is further confirmed by ${ }^{13} \mathrm{C}\left\{{ }^{1} \mathrm{H}\right\}$ CPMAS NMR spectra, displaying the characteristic chemical shifts of BTEB (Figure 6): at $134 \mathrm{ppm}$ which correspond to C-Phenyl and at 58 and $18 \mathrm{ppm}$, attributed to remaining $\mathrm{Si}-\mathrm{OCH}_{2} \mathrm{CH}_{3}$ groups.
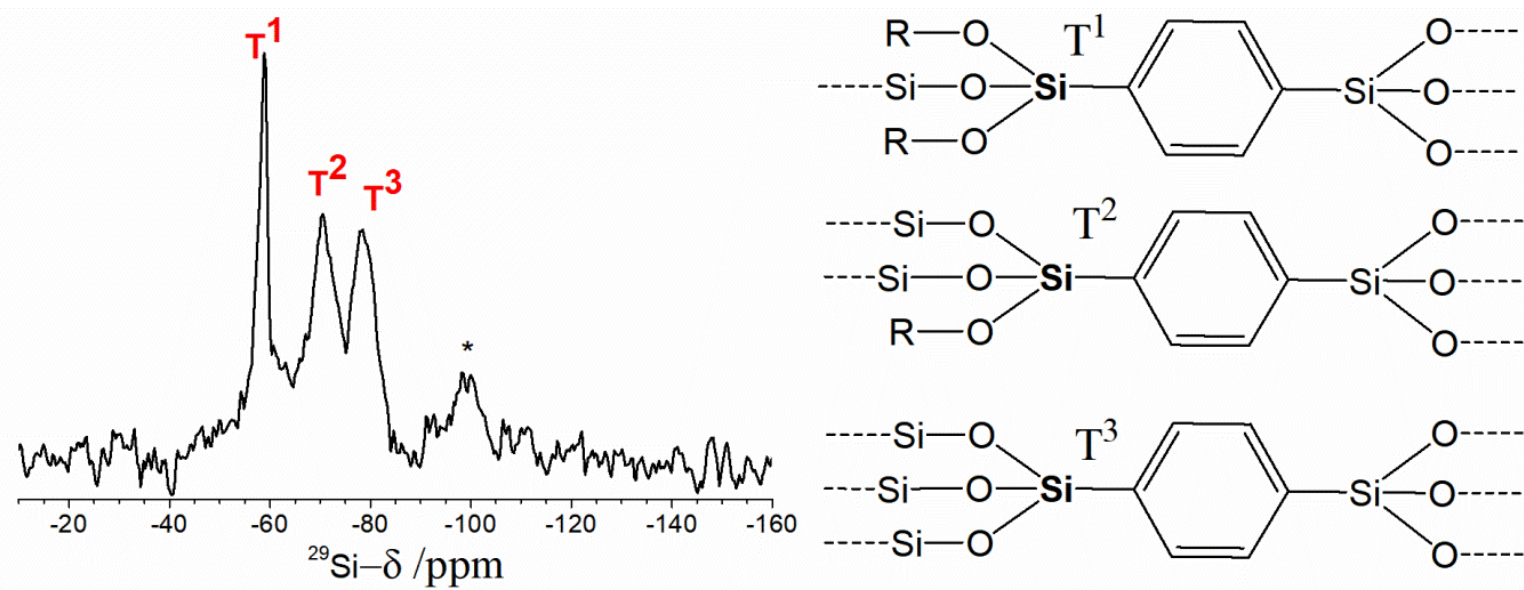

Figure 5. ${ }^{29} \mathrm{Si}\left\{{ }^{1} \mathrm{H}\right\}$ CPMAS NMR spectra of BCM-BTEB sample and schemes showing the attributions to $T^{n} \mathrm{Si}$ groups. $\mathrm{R}$ is either an ethoxy group or hydrogen. The asterisk indicates a background signal from the NMR probe used in the experiment.

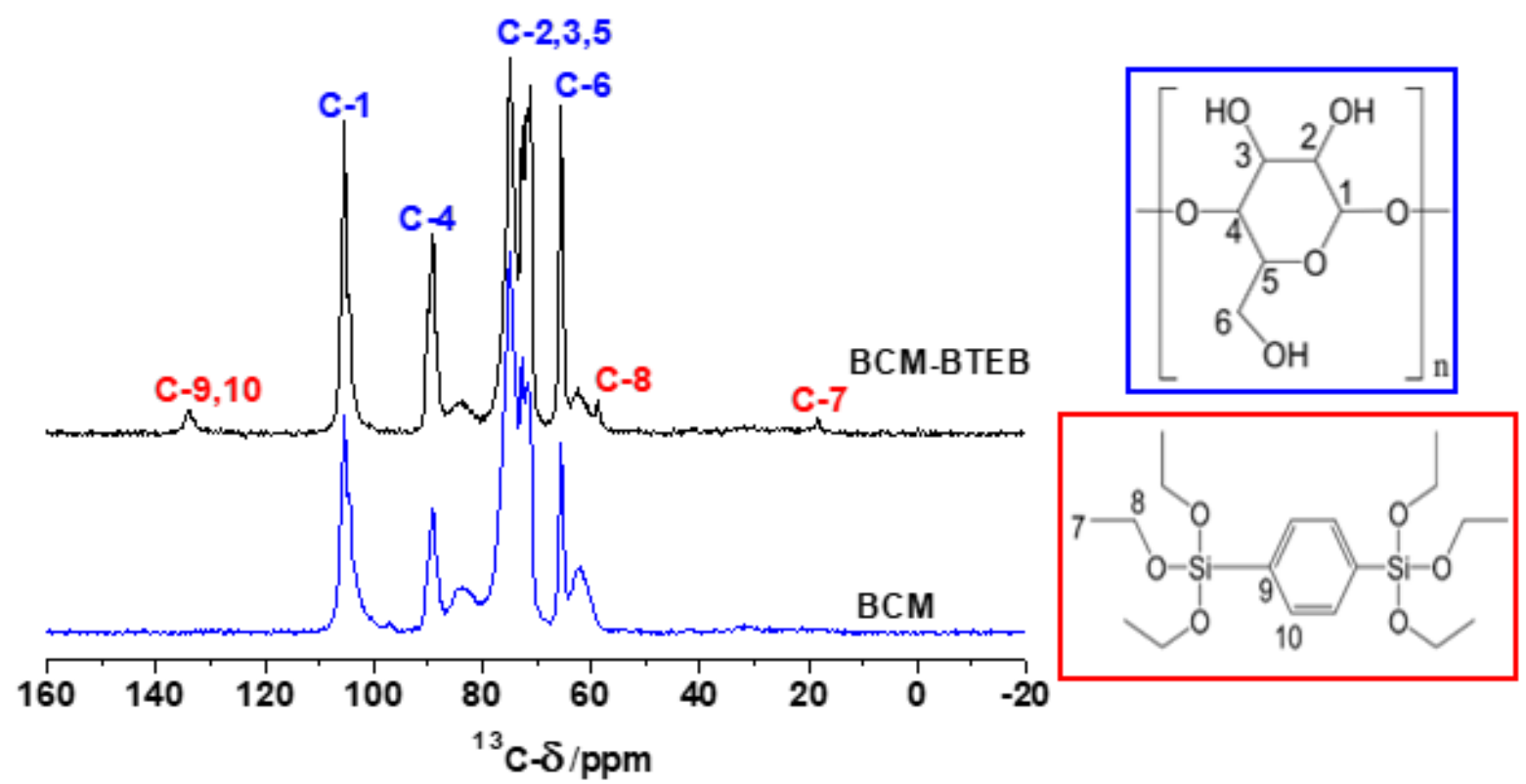

Figure 6. ${ }^{13} \mathrm{C}\left\{{ }^{1} \mathrm{H}\right\}$ CPMAS NMR spectra of the $B C M$ and $B C M-B T E B$ and signal assignments.

Although solid state NMR experiments confirm the presence of BTEB moieties in the final functionalized material BCM-BTEB, the low concentration of these species limits the structural information available from NMR. To obtain more detailed information about the BCM functionalization, DNP enhanced solid state NMR experiments were performed. Figure 7a shows solid 
state ${ }^{13} \mathrm{C}\left\{{ }^{1} \mathrm{H}\right\}$ CPMAS NMR spectra for the BCM-BTEB sample obtained under DNP conditions, with (black curves) and without (grey curves) mw irradiation. The ${ }^{13} \mathrm{C}$ attributions are summarized in Table 1. A $15 \mathrm{mM}$ solution of TEKPol radical in TCE (TEKPol@TCE) was used as polarization matrix, to selectively enhance the ${ }^{13} \mathrm{C}$ NMR signal of the hydrophobic BTEB moieties, as previously suggested by Gutmann and co-workers. ${ }^{57,70}$ Due to the presence of a strong ${ }^{13} \mathrm{C}$ resonance around $77 \mathrm{ppm}$, corresponding to the TCE matrix, we have also performed an experiment using a $15 \mathrm{mM}$ solution of bTbk in DMSO (bTbk@DMSO) as polarization source. This second experiment was used, to discard the presence of extra ${ }^{13} \mathrm{C}$ peaks overlapping with the TCE signal. All peaks observed in this region (around 65 to $80 \mathrm{ppm}$ ) correspond solely to cellulose species C2, C3 and C5, as shown in the NMR results above.

Table $1-{ }^{13} \mathrm{C},{ }^{1} \mathrm{H}$ NMR chemical shift attributions for the BCM and BTEB moieties from DNP NMR experiments. Carbon numbers refers to the labeling in Figure $6 .{ }^{1} \mathrm{H}$ chemical shifts refering to the carbon labeling corresponds to protons directly bonded to the corresponding carbon atom.

\begin{tabular}{cccc}
\hline Molecule & Site & ${ }^{13} \mathrm{C}( \pm 1 \mathrm{ppm})$ & ${ }^{1} \mathrm{H}( \pm 0.2 \mathrm{ppm})$ \\
\hline BCM & 1 & 107 & 4.3 \\
& $2,3,5$ & $72-77$ & - \\
4 & 91 & 3.7 \\
& 6 & 67 & 4.2 \\
BTEB & & & 1.5 \\
& 7 & 21 & 3.8 \\
& 8 & 61 & 7.8 (Shoulder) \\
& 9 & 136 & 7.8 \\
& 10 & 132 & 4.2 \\
\hline
\end{tabular}

For the spectra obtained with TEKPol@TCE matrix, as previously observed for other cellulose-containing materials, ${ }^{57}$ the hydrophobic character of the employed DNP-matrix preferentially enhances the signal from the hydrophobic BTEB moieties (C7-10). Enhancements of around $\varepsilon=35$ to 100 are observed for the ${ }^{13} \mathrm{C}$ lines attributed to BTEB (Enhancements for each line are indicated in Figure 7), while a moderate enhancement of around $\varepsilon=6$ is observed for the ${ }^{13} \mathrm{C}$ lines corresponding to cellulose $(C 1,4,6)$. Unlike standard solid-state NMR experiments described above, for the TEKPol@TCE DNP spectrum the chemical shifts for BTEB phenyl carbons 9 and 10 (around 137 and $131 \mathrm{ppm}$ respectively) can be clearly resolved from each other, confirming the integrity of the BTEB structure. Besides the lines corresponding to carbon groups in cellulose and $B T E B$, two additional lines are observed in the ${ }^{13} C$ DNP spectrum of $B C M-B T E B$ with isotropic shifts around 43 ppm and 35 ppm ( $\mathrm{i}$ and ii) in Figure 7a (upper spectrum)). Both signals are not observed 
for the spectra measured without mw irradiation and can be attributed to unidentified impurities from the synthetic route.
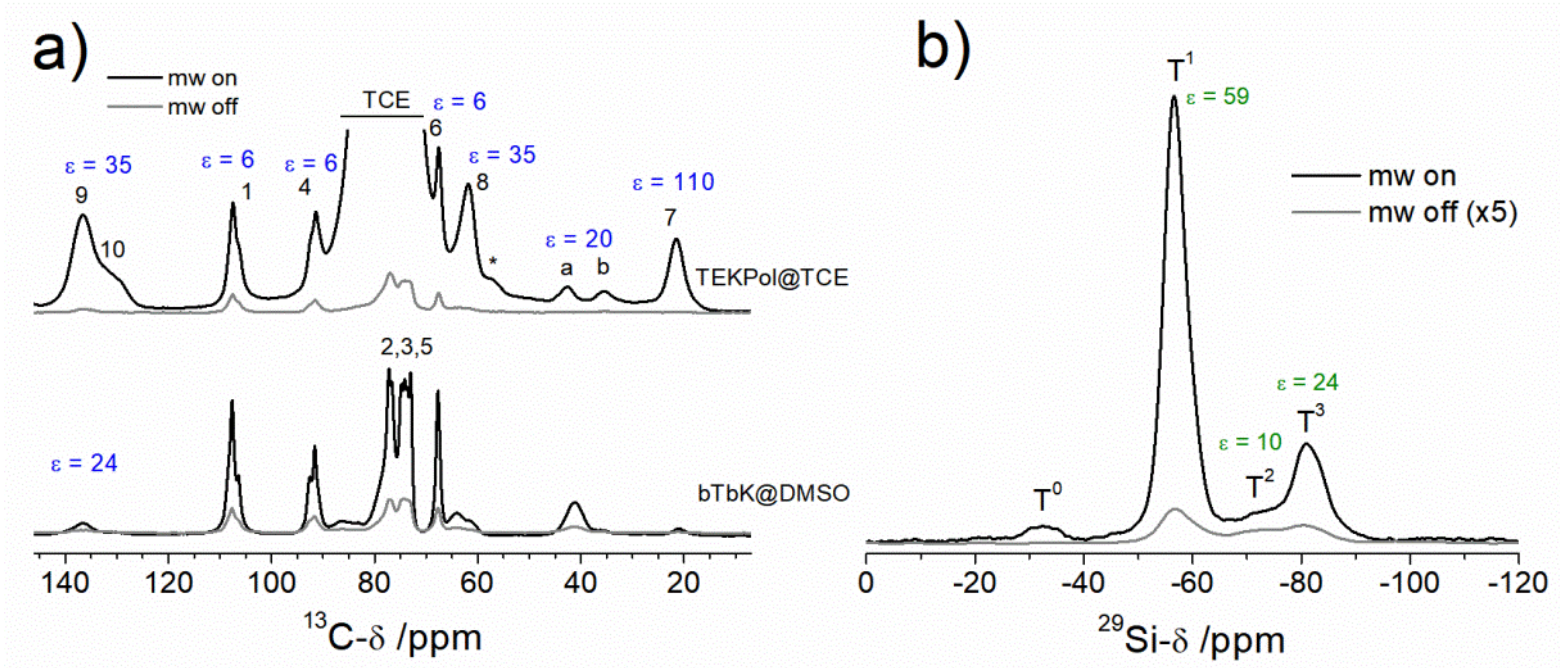

Figure $7-{ }^{13} \mathrm{C}\left\{{ }^{1} \mathrm{H}\right\}$ (a) and ${ }^{29} \mathrm{Si}\left\{{ }^{1} \mathrm{H}\right\}$ (b) CPMAS NMR spectra for the BCM-BTEB sample measured under DNP conditions with (black curves) and without (grey curves) mw irradiation. ${ }^{13} \mathrm{C}$ spectra were measured using two different polarizing matrices, a solution of $15 \mathrm{mM}$ TEKPol in TCE (TEKPol@TCE) and a solution of 15 mM bTbK in DMSO (bTbK@DMSO). ${ }^{29} \mathrm{Si}$ spectra were measured using TEKPol@TCE as polarizing matrix. The DNP 391 enhancements, $\varepsilon$, for each line are indicated in the spectrum. Enhancement for the line around $-32 \mathrm{ppm}$ could not be estimated. The enhancement for the spectrum measured with bTbK@DMSO is the same for all lines. Asterisks indicate spinning sidebands. MAS rate was $8 \mathrm{kHz}$ for all spectra.

Figure $7 \mathrm{~b}$ shows DNP NMR ${ }^{29} \mathrm{Si}\left\{{ }^{1} \mathrm{H}\right\}$ CPMAS spectra measured for the BCM-BTEB compound. The ${ }^{29} \mathrm{Si}$ CPMAS spectrum shows signals in the region expected for $\mathrm{Si}$ species of $\mathrm{T}^{\mathrm{n}}$ type coordinated with phenyl groups $\left(\mathrm{PhSi}(\mathrm{OSi})_{n} \mathrm{R}_{n-1}\right)$, with $\mathrm{n}=1,2,3$ being the number of $\mathrm{Si}-\mathrm{O}-\mathrm{Si}$ linkages per $\mathrm{Si}$ unit and $\mathrm{R}$ being either $\mathrm{CH}_{2}-\mathrm{CH}_{3}$ or $\mathrm{OH}$ groups. ${ }^{71}$ The lines around $-180,-71$ and -57 are attributed respectively to $T^{3}, T^{2}, T^{1}$ while the small hump at $-32 \mathrm{ppm}$ is 1attributed to impurities. $\mathrm{T}^{3}, \mathrm{~T}^{2}, \mathrm{~T}^{1}$ species show DNP enhancements of about 24, 10 and 59, 1respectively. It is well-known that due to its bi-functionality, BTEB tends to form porous 1covalent network structures where phenyl species are interconnected by Si-O-Si linkages. ${ }^{72}$ The differences in enhancements for the various species suggests preferential location of the groups within the nanoparticles. $T^{1}$ and $T^{0}$ groups show the highest enhancements, letting us conclude that these species are mostly located on the surface of the nanoparticles, being more accessible to the polarizing matrix. On the other hand, the relatively high enhancement $(\varepsilon=24)$ for $\mathrm{T}^{3}$ let us assume that these groups are close to the surface of the material, probably cross-linked via $\mathrm{T}^{1}$ groups. The small enhancement for $\mathrm{T}^{2}$ groups indicates that these groups probably belong to polymerized BTEB in the bulk of the material. Due to the bi-functional character of BTEB, any clear attribution to the coordination of $\mathrm{T}^{2}$ and $\mathrm{T}^{3}$ species would require additional experiments, which are beyond the scope of the present work. 

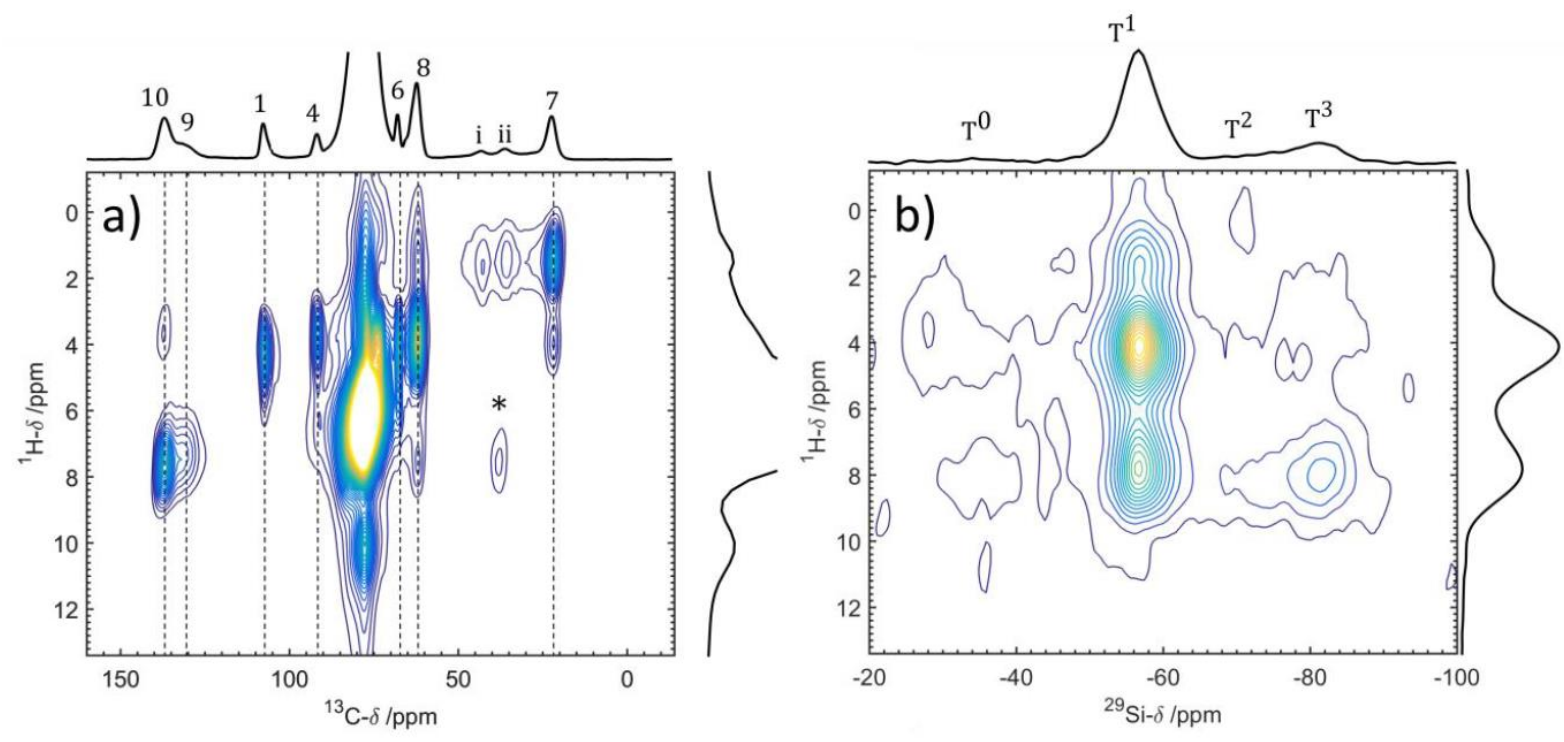

Figure 8 - DNP enhanced ${ }^{13} \mathrm{C}\left\{{ }^{1} \mathrm{H}\right\}(\mathrm{a})$ and ${ }^{29} \mathrm{Si}\left\{{ }^{1} \mathrm{H}\right\}$ (b) FSLG HETCOR NMR spectra for BCM-BTEB. The numbers are attribution to carbon species labelled in Figure 6. Asterisks indicate spinning sidebands.

Figure 8a shows a 2D ${ }^{13} \mathrm{C}\left\{{ }^{1} \mathrm{H}\right\}$ FSLG HETCOR spectrum for BCM-BTEB. Table shows the $1 \mathrm{H}$ chemical shifts for all observed species. Carbons $\mathrm{C} 1,4$ and 6 from $\mathrm{BCM}$ moieties show the expected ${ }^{1} \mathrm{H}$ correlations around $4.3,3.7$ and $4 \mathrm{ppm}$, respectively, in agreement with two dimensional MAS NMR results reported by Kono et al. ${ }^{71}$ The resonance peak for methyl carbon $\mathrm{C7}$ from BTEB shows correlations around $1.5 \mathrm{ppm}$, corresponding to $\mathrm{CH}_{3}$ and around $4 \mathrm{ppm}$, corresponding to the $\mathrm{OCH}_{2}$ protons from the neighbouring $\mathrm{C} 8$ carbon, as confirmed by the strong correlation observed between these protons and $\mathrm{C} 8$. Also, carbon $\mathrm{C} 8$ shows correlation with $\mathrm{CH}_{3}$ protons (1.5 ppm), corresponding to the neighbouring $\mathrm{C} 7$ protons, and an additional correlation with $1 \mathrm{H}$ resonating around 7.8 ppm, which can be attributed to protons from aromatic groups (C10). Carbons C9 and C10 show correlation with aromatic protons, resonating around $7.8 \mathrm{ppm}$. Also, a second correlation peak is observed for $\mathrm{C} 10$ around $3.7 \mathrm{ppm}$, probably corresponding to interaction with $\mathrm{OCH}_{2}$ from alkoxysilane fragments or alternatively, with protons from $\mathrm{C} 6$ species in $\mathrm{BCM}$. The ${ }^{13} \mathrm{C}$ lines around 35 and $43 \mathrm{ppm}$ show correlations with protons resonating at $1.5 \mathrm{ppm}$, leading to the attribution of these impurity species to $\mathrm{CH}_{3}$ or $\mathrm{CH}_{2}$ in aliphatic groups. The origin of these species is still under investigation.

Figure $8 \mathrm{~b}$ shows the DNP enhanced ${ }^{29} \mathrm{Si}\left\{{ }^{1} \mathrm{H}\right\}$ FSLG HETCOR NMR spectrum for the BCM-BTEB sample. The lines corresponding to $\mathrm{T}^{3}$ and $\mathrm{T}^{1}$ groups give the strongest contribution to the HETCOR spectrum, while $\mathrm{T}^{2}$ groups shows only very weak correlation peaks. The $T_{3}$ line shows only one correlation, with ${ }^{1} \mathrm{H}$ species resonating around $7.8 \mathrm{ppm}$, corresponding to protons in the phenyl group from BTEB, as discussed above. On the other hand, besides the correlation with phenyl protons, the $\mathrm{T}^{1}$ line shows correlations with ${ }^{1} \mathrm{H}$ species resonating around $4.3 \mathrm{ppm}$ and $1.5 \mathrm{ppm}$. The line around 1.5 ppm corresponds to $\mathrm{CH}_{2} / \mathrm{CH}_{3}$ groups from the non-hydrolysed ethoxy silyl groups of the organosilane $\mathrm{BTEB}$, as confirmed by ${ }^{13} \mathrm{C}$ NMR results shown above, indicating that the hydrolysis reaction is not complete. The line around $4.3 \mathrm{ppm}$ corresponds to $\mathrm{SiOH}$ species in fully hydrolysed BTEB. For $\mathrm{T}^{0}$ species only a correlation with ${ }^{1} \mathrm{H}$ around $3.7 \mathrm{ppm}$ is observed, which can correspond to hydroxyl groups or protons bonded to carbon $\mathrm{C} 8$, indicating once more that the hydrolysis of BTEB is not complete. As derived above from the strong DNP enhancement for $\mathrm{T}^{0}$ and $\mathrm{T}^{1}$ groups, they correspond to BTEB moieties at the surface of the silicon containing nanoparticles. Adding to this information the 
incomplete hydrolysis observed in the ${ }^{13} \mathrm{C}\left\{{ }^{1} \mathrm{H}\right\}$ HETCOR experiments, we assume that BTEB moieties are covalently attached to the surface of the nanoparticles. Furthermore, the $\mathrm{T}^{0}$ groups are only visible by DNP, which means that they occur in very minor concentration, which underlines that they are most probably not present in the bulk of the particles. To sum up, the tentative binding model of the benzene-silica nanoparticles shown in Figure 9 can be derived. Further investigations are however required to clearly prove this model.

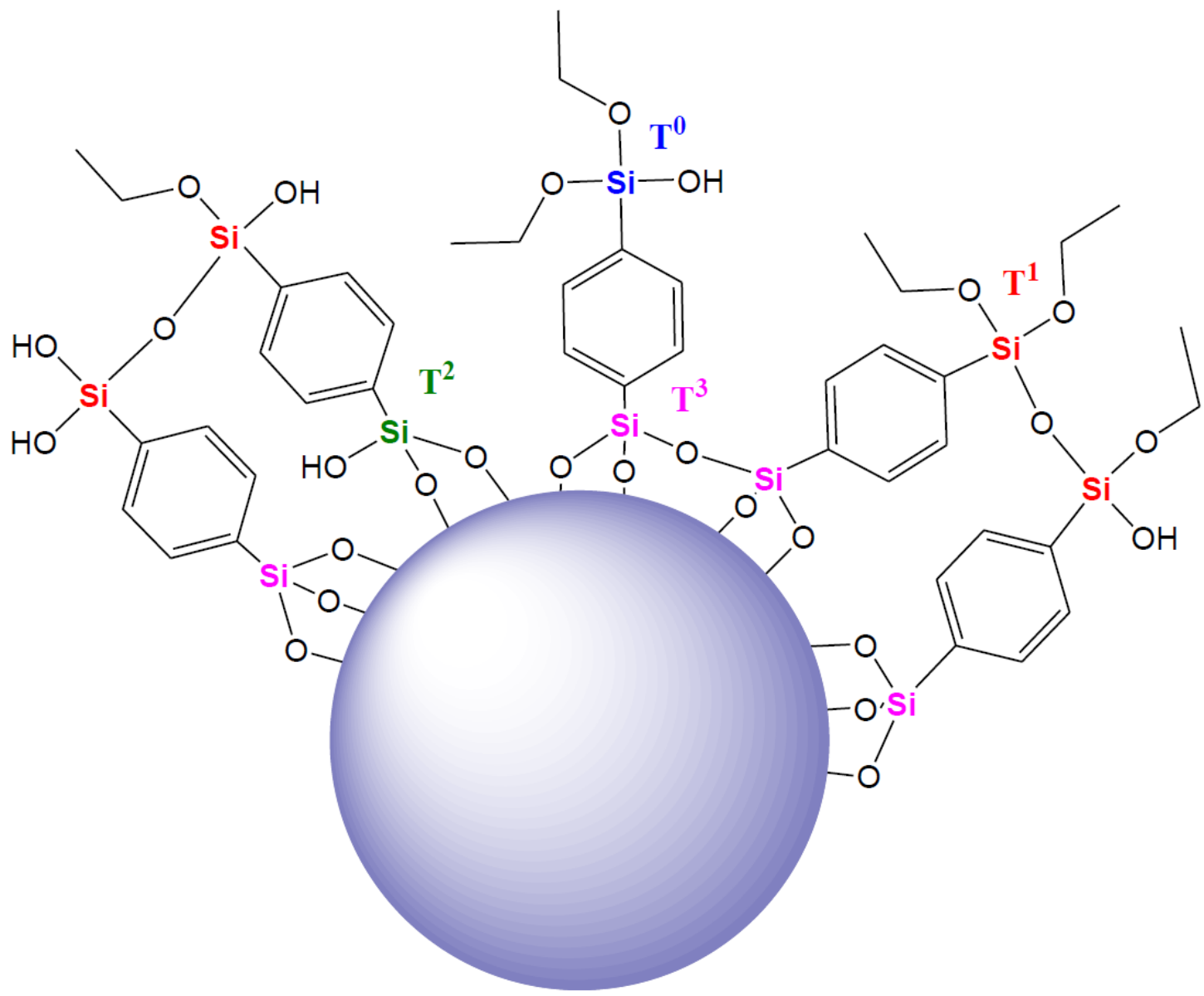

Figure 9 - Illustration of the possible species occurring at the surface of BTEB nanoparticles. The color code refers to the types of Si species $\left(T^{0}, T^{1}, T^{2}\right.$ and $\left.T^{3}\right)$.

The amount of the silica nanoparticles formed after the incorporation of BTEB in the BCM was quantified by TGA. The TGA curves of the BCM and the BCM-BTEB display two significant weight losses: from ambient temperature to $150^{\circ} \mathrm{C}$ and from 150 to $500^{\circ} \mathrm{C}$. The first weight loss is due to membrane dehydration. Physically adsorbed and hydrogen-bonded linked water molecules are removed at this first stage. The second weight is associated to the decomposition of the $B C M .{ }^{4,73}$ From $500{ }^{\circ} \mathrm{C}$, in the $B C M-B T E B$, the residue of $3.2 \%$ is observed which confirms BCM-BTEB mainly consists of organics with a low amount of BTEB. 


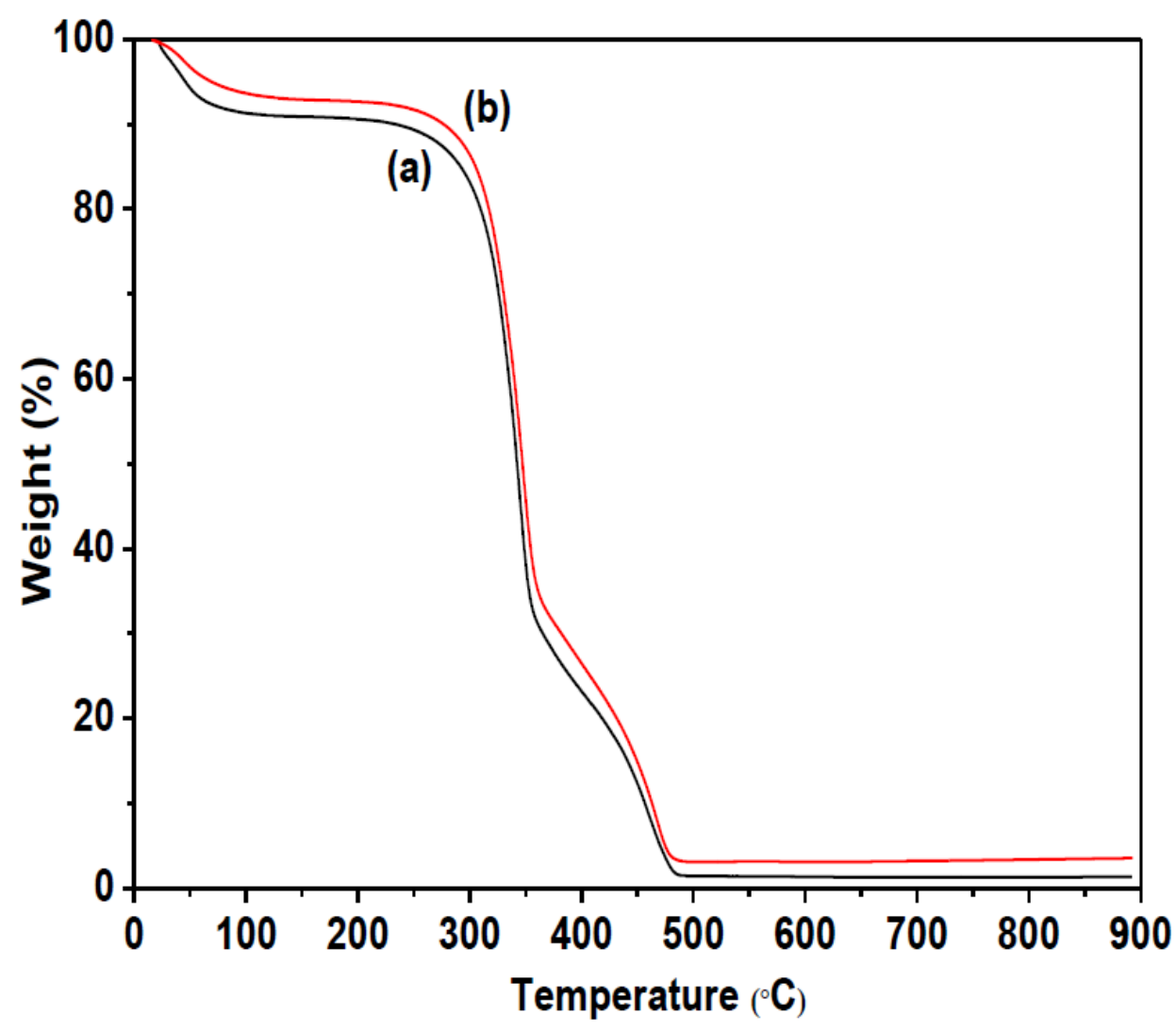

Figure 10. Thermogravimetric curves of (a) $B C M$ and (b) BCM-BTEB, under $\mathrm{O}_{2}$ atmosphere.

\section{CONCLUSION}

The incorporation of BTEB on the surface of BCM has been successfully achieved as demonstrated by the physicochemical characterization. SEM and TEM microscopy show the formation of spherical silica nanoparticles with heterogeneous particle size $(30-100 \mathrm{~nm})$, and probably porous structure, which are homogeneously distributed throughout the BCM surface. Solid state DNPNMR experiments demonstrate the integrity of the BTEB functionalities and its polycondensation (presence of Si-O-Si linkages). They also show the presence of ethoxy silyl groups $\left(\mathrm{SiOCH}_{2} \mathrm{CH}_{3}\right)$ in the final material, indicating that the hydrolysis reaction of BTEB is incomplete. From these experiments a first tentative model of the benzene-silica nanoparticles could be derived which has to be further confirmed by advanced spectroscopic techniques. Altogether, we have demonstrated a simple strategy for the incorporation of porous silica nanoparticles on BCM opening new perspectives for the design of tailored drug-delivery systems which will find application in biomedical area.

\section{ACKNOWLEDGMENTS}

This work has been financial supported by Fundação de Amparo à pesquisa do estado de São Paulo (FAPESP), through project 2015/12908-2 and 2017/21005-1. ASM thanks FAPESP for a grant. MOJr is grateful for a CAPES-Humboldt research fellowship. GB thanks the Deutsche Forschungsgemeinschaft, DFG, for financial support under contract Bu-911-24/2. TG thanks the DFG under contract GU 1650/3-1 for financial support. H. S. Barud thanks CNPq (grant 407822/2018-6), FAPESP (grant 2018/25512-8 and 2013/07793-6). We thank Dr. Olivier Ouari (AixMarseille University) for providing the bTbk radical and André Tobello Foundation for offering the Strain Gluconacetobacter Xylinum (ATCC23760). 


\section{REFERENCES}

(1) Gorgieva, S.; Trček, J. Bacterial Cellulose: Production, Modification and Perspectives in Biomedical Applications. Nanomaterials 2019, 9, 1352-1371.

(2) Wasim, M.; Mushtaq, M.; Khan, S.; Salam, A. An Overview of Synthesized Bacterial Cellulose Nanocomposites for Biomedical Applications. Biomed. J. Sci. \& Tech. Res. 2020, 27, 20653-20656.

(3) Silvestre, A. J. D.; Freire, C. S. R.; Neto, C. P. Do bacterial cellulose membranes have potential in drug-delivery systems? Expert Opinion on Drug Delivery 2014, 11, 113-1124.

(4) Barud, H. S.; Assunção, R. M. N.; Martines, M.A.U.; Dexpert-Ghys, J.; Marques R.F.C.; Massaddeq, Y.; Ribeiro, S. J. L. Bacterial cellulose-silica organic-inorganic hybrids. J. Sol-Gel Sci. Technol. 2008, 46, 363-367.

(5) Jozala, A. F.; Lencastre-Novaes, L. C.; Lopes, A. M.; Santos-Ebinuma, V. C.; Mazzola, P. G.; Pessoa-Jr, A.; Grotto, D.; Gerenutti, M.; Chaud, M. V. Bacterial Nanocellulose Production and application: a 10years overview. Appl. Microbiol. Biotechnol. 2016, 100, 2063-2073.

(6) Almeida, I. F.; Pereira, T.; Silva, N. H. C. S.; Gomes, F. P.; Silvestre, A. J. D.; Freire, C. S. R.; Sousa, J. M. L.; Costa, P. C. Bacterial cellulose membranes as drug delivery systems: an in vivo skin compatibility study. Eur. J. Pharm. Biopharm. 2014, 86, 332-336.

(7) Trovatti, E.; Silva, N. H. C. S.; Duarte, I. F.; Rosado, C. F.; Almeida, I. F.; Costa, P.; Freire, C. S. R.; Silvestre, A. J. D.; Neto, C. P. Biocellulose membrane as supports for dermal release of lidocaine. Biomacromolecules 2011, 12, 4162-4168.

(8) Trovatti, E.; Freire, C. S. R.; Pinto, P. C.; Almeida, I. F.; Costa, P.; Silvestre, A. J. D.; Neto, C. P; Rosado, C. Bacterial cellulose membranes applied in topical and transdermal delivery of lidocaine hydrochloride and ibuprofen: in vitro diffusion studies. Int. J. Pharm. 2012, 435, 83-87.

(9) Silva, N. H. C. S.; Drumond, I.; Almeida, I. F.; Costa, P.; Rosado, C. F.; Neto, C. P.; Freire, C. S. R.; Silvestre, A. J. D. Topical caffeine delivery using biocellulose membranes: a potential innovative system for cellulite treatment. Cellulose 2014, 21, 665-674.

(10) Stoica-Guzun, A.; Stroescu, M.; Tache, F.; Zaharescu, T.; Grosu, E. Effect of electron beam irradiation on bacterial cellulose membranes used as transdermal drug delivery systems. Nucl. Instrum. Meth. Phys. Res. B 2007, 265, 434-438.

(11) Jipa, I. M.; Stoica-Guzun, A.; Stroescu, M. Controlled release of sorbic acid from bacterial cellulose based mono and multilayer antimicrobial films. LWT-Food Sci. Technol. 2012, 47, 400-406.

(12) Halib, N.; Amin, M. C. I. M.; Ahmad, I.; Hashim, Z. M.; Jamal, N. Swelling of bacterial celluloseacrylic acid hydrogels: sensitivity towards external stimuli. Sains Malay. 2009, 38, 785-791.

(13) Chen, P. Y.; Lai, J. T.; Hsiao, H. C.; Chu, Y.; Liao, C. C. Bacterial cellulose composite with capsules embedded therein and preparation thereof. US8871743B2. 02-06-2011.

(14) Serafica, G.; Mink, R.; Hoon, R.; Damien, C. Microbial cellulose materials for use in transdermal drug delivery systems, methods of manufacture and use. EP184943A2. 19-04-2006.

(15) Bayon, Y.; Ladet, S.; Lefranc, O.; Gravagna, P. Medical device including bacterial cellulose reinforced by resorbable or non-resorbable materials. WO2010052586A1. 07-11-2008. 
(16) Lin, Y.-C.; Wey, Y.-C.; Lee, M.-L. Bacterial cellulose film and uses thereof. US8772003B2. 24-052010.

(17) Trexler, M. M.; Graham, J. L.; Breidenich, J. L.; Maranchi, J. P.; Patrone, J. B.; Patchan, M. W.; Elisseeff, J. H.; Calderon-Colon, X. US20130032059A1. 03-08-2011.

(18) Carvalho, G. C.; Sábio, R. M.; Ribeiro, T. C.; Monteiro, A. S.; Pereira, D. V.; Ribeiro, S. J. L.; Chorilli, M. Highlights in Mesoporous Silica Nanoparticles as a Multifunctional Controlled Drug Delivery Nanoplatform for Infectious Diseases Treatment. Pharm. Res. 2020, 37, 191-221.

(19) Chen, W.; Glackin, C. A.; Horwitz, M. A.; Zink, J. I. Nanomachines and other caps on mesoporous silica nanoparticles for drug delivery. Acc. Chem. Res. 2019, 52, 1531-1542.

(20) Manzano, M.; Vallet-Regí, M. Mesoporous silica nanoparticles for drug delivery. Adv. Funct. Mater. 2019, 30, 190263-190276.

(21) Baeza, A.; Ruiz-Molina, D.; Vallet-Regí, M. Recent advances in porous nanoparticles for drug delivery in antitumoral applications: inorganic nanoparticles and nanoscale metal-organic frameworks. Expert Opin. Drug Deliv. 2017, 14, 783-796.

(22) Lu, J.; Liong, M.; Li. Z.; Zink, J.I.; Tamanoi F. Biocompatibility, biodistribution, and drug-delivery efficiency of mesoporous silica nanoparticles for cancer therapy in animals. Small 2010, 6, 1794-1805.

(23) Narayan, R.; Nayak, U.; Raichur, A.; Garg, S. Mesoporous silica nanoparticles: a comprehensive review on synthesis and recent advances. Pharmaceutics 2018, 10, 118-167.

(24) Giret, S.; Wong, C. M. M.; Carcel, C. Mesoporous-silica-functionalized nanoparticles for drug delivery. Chem. Eur. J. 2015, 21, 13850-13865.

(25) Flodström, K.; Wennerström, H.; Alfredsson, V. Mechanism of mesoporous silica formation. A time-resolved NMR and TEM study of silica-block copolymer aggregation. Langmuir 2004, 20, 680688.

(26) Poscher, V.; Salinas, Y. Trends in Degradable Mesoporous Organosilica-Based Nanomaterials for Controlling Drug Delivery: A Mini Review. Materials 2020, 13, 3668-3391.

(27) Du, X.; Li, X.; Zhang, X.; Kleitz, F.; Qiao, S. Z. Mesoporous silica nanoparticles with organo-bridged silsesquioxane framework as innovative platforms for bioimaging and therapeutic agent delivery. Biomaterials 2016, 91, 90-127.

(28) Cho, E. B.; Kim, D.; Jaroniec, M. Preparation of mesoporous benzene-silica nanoparticles. Microporous and Mesoporous Mat. 2009, 120, 252-256.

(29) Croissant, J.G.; Cattoën, X.; Wong, C. M. M.; Durand, J. O.; Kashab, N. M. Syntheses and applications of periodic mesoporous organosilica nanoparticles. Nanoscale 2015, 7, 20318-20334.

(30) Shi, J. Y.; Wang, C. A.; Li, Z. J.; Wang, Q. Y.; Zhang, W. W., Heterogeneous organocatalysis at work: functionalization of hollow periodic mesoporous organosilica spheres with MacMillan catalyst. Chem. Eur. J. 2011, 17, 6206-6213.

(31) Croissant, J.; Salles, D.; Maynadier, M.; Mongin, O.; Hugues, V.; Blanchard- Desce, M. Mixed periodic mesoporous organosilica nanoparticles and core-shell systems, application to in vitro twophoton imaging, therapy and drug delivery. Chem. Mater. 2014, 16, 7214-7220. 
(32) Haffer, S.; Tiemann, M.; Fröba, M. Periodic mesoporous organosilica (PMO) materials with uniform spherical core-shell structure. Chem. Eur. J. 2010, 16, 10447-10452.

(33) Cho, E. B.; Kim, D. Direct Synthesis of sulfonic acid-functionalized periodic mesoporous benzenesilicas with large pores. J. Phys. Chem. Solids 2008, 69, 1142-1146.

(34) Morell, J.; Güngerich, M.; Wolter, G.; Jiao, J.; Hunger, M.; Klar, P.; Fröba, M. Synthesis and characterization of highly ordered biofunctional aromatic periodic mesoporous organosilicas with different pore sizes. J. Mater. Chem. 2006, 16, 2809-2818.

(35) Li, X.; Janke, A.; Formanek, P.; Fery, A.; Stamm, M.; Tripathi, B. High permeation and antifouling polysulfone ultrafiltration membranes with in situ synthesized silica nanoparticles. Mater. Today Commun. 2020, 22, 100784.

(36) Hou, H.; Duan, C.; Zhu, G.; Luo, H.; Liang, S.; Jin, Y.; Zhao, N.; Xu, J. Functional bacterial cellulose membranes with 3D porous architectures: Conventional drying, tunable wettability and water/oil separation. J. Membr. Sci. 2019, 591, 117312.

(37) Shen, Z.; Cai, N.; Xue, Y.; Chan, V.; Yu, B.; Wang, J.; Song, H.; Deng, H.; Yu, F. Engineering Sustainable Antimicrobial Release in Silica-Cellulose Membrane with $\mathrm{CaCO}_{3}$-Aided Processing for Wound Dressing Application. Polymers. 2019, 11, 808-826.

(38) Barnes, A. B.; Paëpe, G. D.; Van der Wel, P. C. A.; Hu, K. N.; Joo, C. G.; Bajaj, V. S.; Mak-Jurkauskas M. L.; Sirigiri, J. R.; Herzfeld, J.; Temkin, R. J.; et al. High-Field Dynamic Nuclear Polarization for Solid and Solution Biological NMR. App. Magn. Reson. 2008, 34, 237-263.

(39) Maly, T.; Debelouchina, G. T.; Bajaj, V. S.; Hu, K. N.; Joo, C. G.; Mak-Jurkauskas, M. L.; Sirigiri, J. R.; van der Wel, P. C. A.; Herzfeld, J.; Temkin, R. J.; et al. Dynamic nuclear polarization at high magnetic fields. J. Chem. Phys. 2008, 128, 052211-052219.

(40) Ni, Q. Z.; Daviso, E.; Can, T. V.; Markhasin, E.; Jawla, S. K.; Swager, T. M.; Temkin, R. J.; Herzfeld, J.; Griffin, R. G. High frequency dynamic nuclear polarization. Acc. Chem. Res. 2013, 46, 1933-1941.

(41) Griffin, R. G. Clear signals from surfaces. Nature 2010, 468, 381-382.

(42) Lesage, A.; Lelli, M.; Gajan, D.; Caporini, M. A.; Vitzthum, V.; Mieville, P.; Alauzun, J.; Roussey, A.; Thieuleux, C.; Mehdi, A.; et al. Surface Enhanced NMR Spectroscopy by Dynamic Nuclear Polarization. J. Am. Chem. Soc. 2010, 132, 15459-15461.

(43) Rossini, A. J.; Zagdoun, A.; Lelli, M.; Lesage, A.; Coperet, C.; Emsley, L. Dynamic Nuclear Polarization Surface Enhanced NMR Spectroscopy. Acc. Chem. Res. 2013, 46, 1942-1951.

(44) Tanaka, S.; Liao, W. C.; Ogawa, A.; Sato, K.; Coperet, C. DNP NMR spectroscopy of cross-linked organic polymers: rational guidelines towards optimal sample preparation. Phys. Chem. Chem. Phys. 2020, 22, 3184-3190.

(45) Le, D.; Casano, G.; Phan, T. N. T.; Ziarelli, F.; Ouari, O.; Aussenac, F.; Thureau, P.; Mollica, G.; Gigmes, D.; Tordo, P.; et al. Brute-force solvent suppression for DNP studies of powders at natural isotopic abundance. Nucl. Magn. Reson. 2019, 99, 15-19.

(46) Sauvée, C.; Rosay, M.; Casano, G.; Aussenac, F.; Weber, R. T.; Ouari, O.; Tordo, P. Highly efficient, water-soluble polarizing agents for dynamic nuclear polarization at high frequency. Angew. Chem. Int. Ed. Engl. 2013, 4, 10858-10861. 
(47) Zagdoun, A.; Casano, G.; Ouari, O.; Schwarzwälder, M.; Rossini, A. J.; Aussenac, F.; Yulikov, M.; Jeschke, G.; Copéret, C.; Lesage, A.; et al. Large Molecular Weight Nitroxide Biradicals Providing Efficient Dynamic Nuclear Polarization at Temperature up to 200 K. J. Am. Chem. Soc. 2013, 135, 1279012797.

(48) Overhauser, A. W. Polarization of Nuclei in Metals. Phys. Rev. 1953, 92, 411-415.

(49) Thurber, K. R.; Tycko, R. Recent Advances in Solid-State White Ligght-Emitting Electrochemical Cells. Isr. J. Chem. 2014, 54, 855-866.

(50) Hooper, R. W.; Klein, B. A.; Michaelis, V. K. Dynamic Nuclear Polarization (DNP) 101: A New Era for Materials. Chem. Mater. 2020, 32, 4425-4430.

(51) Rankin, A. G. M.; Trebosc, J.; Pourpoint, F.; Amoureux, J. P.; Lafon, O. Recent development in MAS DNP-NMR of materials. Solid State Nucl. Magn. Reson. 2019, 101, 116-143.

(52) Thankamony, A. S. L.; Wittmann, J. J.; Kaushik, M.; Corzilius, B. Dynamic nuclear polarization for sensitivity enhancement in modern solid-state NMR. Prog. Nucl. Magn. Reson. Spectrosc. 2017, 103, 120-195.

(53) Kumar, A.; Durand, H.; Zeno, E.; Balsollier, C.; Watbled, B.; Sillard, C.; Fort, S.; Baussanne, I.; Belgacem, N.; Lee, D.; et al. The surface chemistry of a nanocellulose drug carrier unraveled by MAS-DNP. Chem. Sci. 2020, 11, 3868-3877.

(54) Perras, F. A.; Luo, H.; Zhang, X. M.; Mosier, N. S.; Pruski, M.; Abu-Omar, M. M. Atomic-Level Structure Characterization of Biomass Pre- and Post-Lignin Treatment by Dynamic Nuclear Polarization-Enhanced Solid-State NMR. J. Phys. Chem. A, 2017, 121, 623-630.

(55) Zhao, L.; Smolarkiewicz, I.; Limbach, H.-H.; Breitzke, H.; Pogorzelec-Glaser, K.; Pankiewicz, R.; Tritt-Goc, J.; Gutmann, T.; Buntkowsky, G. Imidazole Doped Cellulose as Membrane for Fuel Cells - Structural and Mechanistic Insights from Solid-State NMR. J. Phys. Chem. C 2016, 120, 1957419585.

(56) Zhao, L.; Li, W.; Plog, A.; Xu, Y. P.; Buntkowsky, G.; Gutmann, T.; Zhang, K. Multi-responsive cellulose nanocrystal-rhodamine conjugates: and advanced structure study by solid-state dynamic nuclear polarization (DNP) NMR. Phys. Chem. Chem. Phys. 2014, 16, 26322-26329.

(57) Gutmann, T.; Kumari, B.; Zhao, L.; Breitzke, H.; Schöttner, S.; Rüttiger, C.; Gallei, M. Dynamic Nuclear Polarization Signal Amplification as a Sensitive Probe for Specific Functionalization of Complex Paper Substrates. J. Phys. Chem. C 2017, 121, 3896-3903.

(58) Shea, K. J.; Loy, D. A.; Webster, O. Arylsilsesquioxane gels and related materials. New hybrids of organic and inorganic networks. J. Am. Chem. Soc. 1992, 114, 6700-6710.

(59) Pecorano E.; Manzani D.; Messadeq Y.; Ribeiro S. J. L. Monomers, Polymers and Composites from Renewable Resources, 1st Ed. Elsevier Science, 2008.

(60) Bennett, A. E.; Rienstra, C. M.; Auger, M.; Lakshmi, K. V.; Griffin, R. C. Heteronuclear decoupling in rotating solids. Chem. Phys. 1995, 103, 6951-6958.

(61) Zagdoun, A.; Casano, G.; Ouari, O.; Lapadula, G.; Rossini, A. J.; Lelli, M.; Baffert, M.; Gajan, D.; Veyre, L.; Maas, W. E.; et al. A Slowly Relaxing Rigid Biradical for Efficient Dynamic Nuclear 
Polarization Surface-Enhanced NMR Spectroscopy: Expeditious Characterization of Functional Group Manipulation in Hybrid Materials. J. Am. Chem. Soc. 2012, 134, 2284-2291.

(62) Takeshi Kobayashi; Lafon, O.; Thankamony, A. S. L.; Slowing, I. I.; Kapil Kandel, D. C.; Vitzthum, V.; Vezin, H.; Amoureux, J.-P.; Bodenhausence, G.; Pruski, M. Analysis of Sensitivity Enhancement by Dynamic Nuclear Polarization in Solid-State NMR: A Case Study of Functionalized Mesoporous Materials. Phys. Chem. Chem. Phys. 2013, 15, 5553-5562.

(63) Fung, B. M.; Khitrin, A. K.; Ermolaev, K. An Improved Broadband Decoupling Sequence for Liquid Crystals and Solids. J. Magn. Reson. 2000, 142, 97-101.

(64) Van Rossum, B. J.; Förster, H.; de Groot, H. J. M. High-Field and High-Speed CP-MAS ${ }^{13} \mathrm{C}$ NMR Heteronuclear Dipolar-Correlation Spectroscopy of Solids with Frequency-Switched Lee-Goldburg Homonuclear Decoupling. J. Magn. Reson. 1997, 124, 516-519.

(65) Osei-Prempeh, G.; Lehmeler, H-J.; Miller, A-F.; Knutson, B. L.; Rankin, S. E. Fluorocarbon and hydrocarbon functional group incorporation into nanoporous silica employing fluorinated and hydrocarbon surfactants as templates. Micropor. Mesopor. Mater. 2010, 129, 189-199.

(66) Socrates, G. Infrared and Raman Characteristic Group Frequencies: Tables and Charts, 3rd ed.; John Wiley \& Sons Ltd.: Chichester, U. K, 2004.

(67) Ou, D. L.; Seddon, A. B. Near-and mid-infrared spectroscopy of sol-gel derived ormosils: vinyl and phenyl silicates. J. Non-Cryst. Solids 1997, 210, 187-203.

(68) Pereira, C.; Alves, C.; Monteiro, A.; Magén, C.; Pereira, A. M.; I Ibarra, A.; Ibarra, M. R.; Tavares, P. B.; Araújo, J. P.; Blanco, G.; et al. Designing Novel Materials by One-Pot Co-condensation: From Hydrophobic Mesoporous Silica Nanoparticles to Superamphiphobic Cotton Textiles. App. Mater. Interfaces 2011, 3, 2289-2299.

(69) Small, J. H.; Shea, K. J.; Loy, D. A. Arylene- and alkylene-bridged polysilsesquioxanes. J. Non. Cryst. Solids 1993, 160, 234-246.

(70) Schäfer, T.; Vowinkel, S.; Breitzke, H.; Gallei, M.; Gutmann, T. Selective DNP Signal Amplification to Probe Structures of Core-Shell Polymer Hybrid Nanoparticles. J. Phys. Chem. C 2019, 123, 644-652.

(71) Kono, H.; Numata, Y.; Erata, T.; Takai, M. $13 \mathrm{C}$ and 1H Resonance Assignment of Mercerized Cellulose II by Two-Dimensional MAS NMR Spectroscopies. Macromolecules 2004, 37, 5310-5316.

(72) Saito, H.; Nishio, Y.; Kobayashi, M.; Sugahara, Y. Hydrolysis behavior of a precursor for a bridged polysilsesquioxane 1,4-bis(triethoxysilyl)benzene: a 29Si NMR study. J. Sol-Gel Sci Technol. 2011, 57, 51-56.

(73) Monteiro, A.S.; Domeneguetti, R. R.; Wong Chi Man, M.; Barud, H. S.; Teixeira-Neto, E.; Ribeiro, S. J. L. Bacterial cellulose-SiO2@TiOz organic-inorganic hybrid membranes with self-cleaning properties. J. Sol-Gel Sci. Techn. 2019, 89, 2-11. 
Table of Content (TOC)

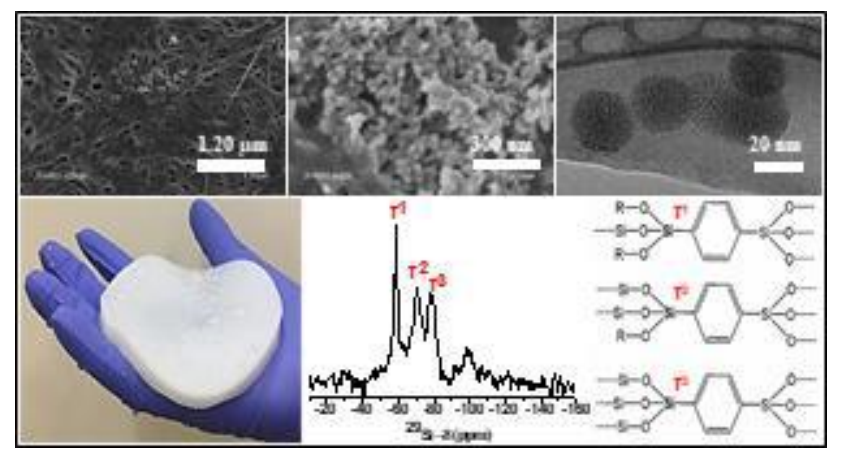

